\title{
Original Study
}

Robert H. Tykot*

\section{Geological Sources of Obsidian on Lipari and Artifact Production and Distribution in the Neolithic and Bronze Age Central Mediterranean}

https://doi.org/10.1515/opar-2019-0007

Received October 2, 2018; accepted December 31, 2018

\begin{abstract}
The Aeolian island of Lipari, just north of eastern Sicily, was a major geological source of high quality obsidian that was volcanically formed in the Late Mesolithic, followed by another major production in the 1st millennium AD. A much earlier volcanic event on Lipari also produced some obsidian, but not of sufficient quality for tool production. A detailed geological survey of the Lipari obsidian source areas, including assessments of quantity, quality, accessibility, and visual variation was performed, followed by elemental analyses using INAA, LA-ICP-MS, ED-XRF, and pXRF which show that many different groups may be distinguished from each other. Geochemical analyses of several thousand obsidian artifacts from sites in Sicily and southern Italy reveal that two early Holocene subsources, Gabellotto Gorge and Canneto Dentro, were used during the Neolithic and Bronze Ages.
\end{abstract}

Keywords: obsidian, Lipari, subsources, trade, Neolithic

\section{Introduction}

The purpose of this study was to broaden our knowledge of the prehistoric Lipari obsidian trade network by chemically analyzing specific geological outcrops and distinguishing subsources of Lipari obsidian in order to identify and address potentially different material quality and quantity, accessibility, territorial control, and tool production and distribution in the central Mediterranean. Obsidian is a volcanic glass that was commonly used in the production of stone tools during the Neolithic and Bronze Age periods (ca. 6000-1000 BC) in the central Mediterranean. Workable quality obsidian that was available in prehistory has been identified as coming from four volcanic islands off the western and southern coasts of Italy: Sardinia, Palmarola, Pantelleria, and Lipari. Obsidian can be chemically characterized by a variety of analytical methods, including instrumental neutron activation analysis (INAA), laser ablation ICP mass spectrometry (LA-ICP-MS), and portable X-ray fluorescence (pXRF), which allows researchers to differentiate most if not all geological sources. The identification of the source of obsidian artifacts allows archaeologists to reconstruct prehistoric trade networks and patterns of socioeconomical interaction by tracing the distribution of obsidian from community to community over time and space.

Article note: This article is a part of Topical Issue on Scientific Studies of Obsidian Sources and Trade, edited by Robert $\mathrm{H}$. Tykot, Maria Clara Martinelli, Andrea Vianello

*Corresponding author: Robert H. Tykot, University of South Florida, Tampa, FL 33556, USA, E-mail: rtykot@usf.edu 


\section{Geological Background}

Lipari is one of seven volcanic islands in the Aeolian Archipelago (also Alicudi, Filicudi, Panarea, Salina, Stromboli, Vulcano), off the northeastern coast of Sicily and not far from the straits of Messina (Figure 1). These islands span a distance of about $75 \mathrm{~km}$ east-west, and $50 \mathrm{~km}$ north-south, while Lipari is located in the southeast quadrant, $30 \mathrm{~km}$ from Sicily. At $37.6 \mathrm{~km}^{2}$, Lipari is also the largest of the Aeolian islands. Lipari was the second of these islands to be formed by subaerial volcanic activity (ca. 267-256 ka), and the first to produce any obsidian, on its southern end with the Monte Guardia eruptions dated ca. 27-24 cal ka (Forni et al., 2013, p. 245). Survey conducted in this area by the author, however, has not found any geological samples sufficiently large enough to produce stone tools (Tykot et al., 2006). In the early Holocene, however, high quality obsidian outcrops were formed in the Vallone del Gabellotto-Monte Pilato in eastern Lipari. Early fission track dating studies of obsidian artifacts had already indicated the rather late geological formation time for Lipari-Gabellotto, which was the most recent of all of the Mediterranean obsidian sources (Arias-Radi et al., 1972; Arias et al., 1984; Bigazzi \& Bonadonna, 1973; Keller, 1970; Wagner et al., 1976), but the precision of such measurements, which range over at least a few thousand years, is insufficient to address the specific cultural time frame when Lipari obsidian first became available.

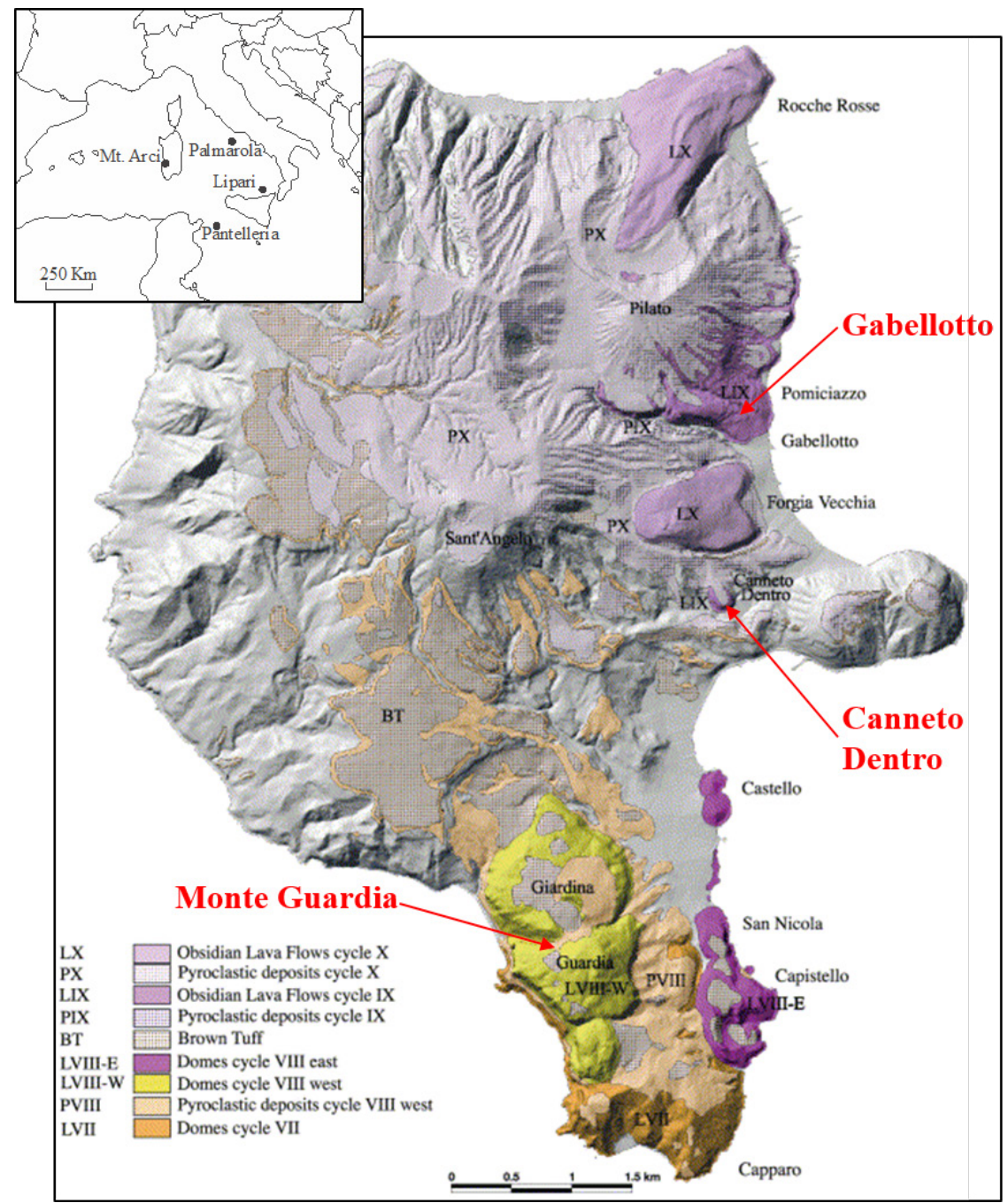

Figure 1. Geological map of Lipari draped on a DEM shaded relief image (modified after Pichler, 1980, Crisci et al., 1991, and Gioncada et al., 2003). The flows for Gabellotto Gorge and Canneto Dentro are dated to the LIX (obsidian lava flows cycle IX) volcanic event. 
Radiocarbon dating has been used to date the Vallone del Gabellotto-Monte Pilato marker bed to 8.7-8.4 kya (Gioncada et al., 2003, p. 198; Forni et al., 2013, pp. 246-247), but this date is based on a single radiocarbon date of $7770 \pm 70$ obtained on foraminifera from an Adriatic Sea core with rhyolitic tephra named E-1 which is attributed to the Gabellotto eruption (Siani et al., 2004; Zanchetta et al., 2011). The 2-sigma calibrated range of 6780-6450 cal BC for this sample is just a few hundred years prior to the beginning of the Early Neolithic in southern Italy. The Vallone Canneto Dentro eruptive formation is stratigraphically beneath that of Gabellotto, but has not been directly dated. It is only exposed now in a small area to the southeast of Gabellotto.

Volcanic activity on Lipari was quiescent then until historic times when eruptions from the side of Mt. Pelato in the northeastern quarter of Lipari buried much of the prehistoric archaeological record with up to 300 meters of pumice and other volcanic debris, first at Forgia Vecchia about $776 \mathrm{AD}$, and then at Rocche Rosse-Lami about 1200 AD (Forni et al., 2013). The obsidian produced in these historical eruptions is of comparable high quality and size, making it easily confused visually with that of prehistoric age. Obsidian also formed on the island of Vulcano in the 1700s AD.

\section{Archaeological Background}

Lipari appears to have been first settled in the Early Neolithic, ca. 5500 BC, in parallel to the westward spread from the Eastern Mediterranean of domesticated plants and animals, and use of ceramics. The excavated Middle Neolithic (Stentinello culture) site of Castellaro Vecchio in Quattropani, and the Late Neolithic site (Diana culture) of Contrada Diana, have revealed extensive obsidian production at a scale far beyond the needs of the modest number of people living on Lipari (Bernabò Brea \& Cavalier, 1957, 1960; Martinelli, 2016; Martinelli et al., 2019). Unfortunately, our knowledge of activity on Lipari itself will remain limited due to the destruction and/or coverage by pumice from the historic eruptions.

The earliest known evidence of the exploitation of Lipari obsidian comes from artifacts at sites in Sicily and mainland Italy dating to the beginning of the Early Neolithic, ca. 6000 BC. This is suggestive that the knowledge of the Gabellotto obsidian flow was acquired relatively quickly after the eruption of Mt. Pelato in the Late Mesolithic, with visits to Lipari part of the overall exploration and settlement by agriculturalists at the beginning of the Neolithic. This appears to coincide with the earliest use of obsidian from Palmarola, Pantelleria, and Sardinia as well. By slightly later phases of the Early Neolithic, Lipari obsidian was distributed to sites throughout the Italian peninsula, into southern France, and across the Adriatic to Croatia (Crisci et al., 1994; De Francesco et al., 2011; Tykot, 2017a).

Archaeologists and geologists have generally thought that the obsidian flow which was utilized during the Neolithic period is today primarily exposed only in the Gabellotto Gorge area along the southern edge of Mt. Pelato.

\section{Field Survey}

Starting in 2000, a field survey on Lipari was initiated with permission from the Soprintendenza della Provincia di Messina, and funding from the National Science Foundation (BCS-0075535) as part of a larger study that also included the obsidian sources and subsources on the islands of Palmarola and Pantelleria. The members of the team collected obsidian geological materials during field visits to Lipari in 2000, 2001, 2002, and 2005. The team surveyed and collected more than 1300 geological specimens of obsidian from both previously identified well-known locations as well as new find spots (Figure 2). The waypoints of more than 40 findspots were recording using GPS, including Canneto Dentro, Forgia Vecchia, Gabellotto, Pomiciazzo, Monte Guardia, Rocche Rosse, and others along the northern and eastern coast and inland areas of Lipari (Figures 3-7). 


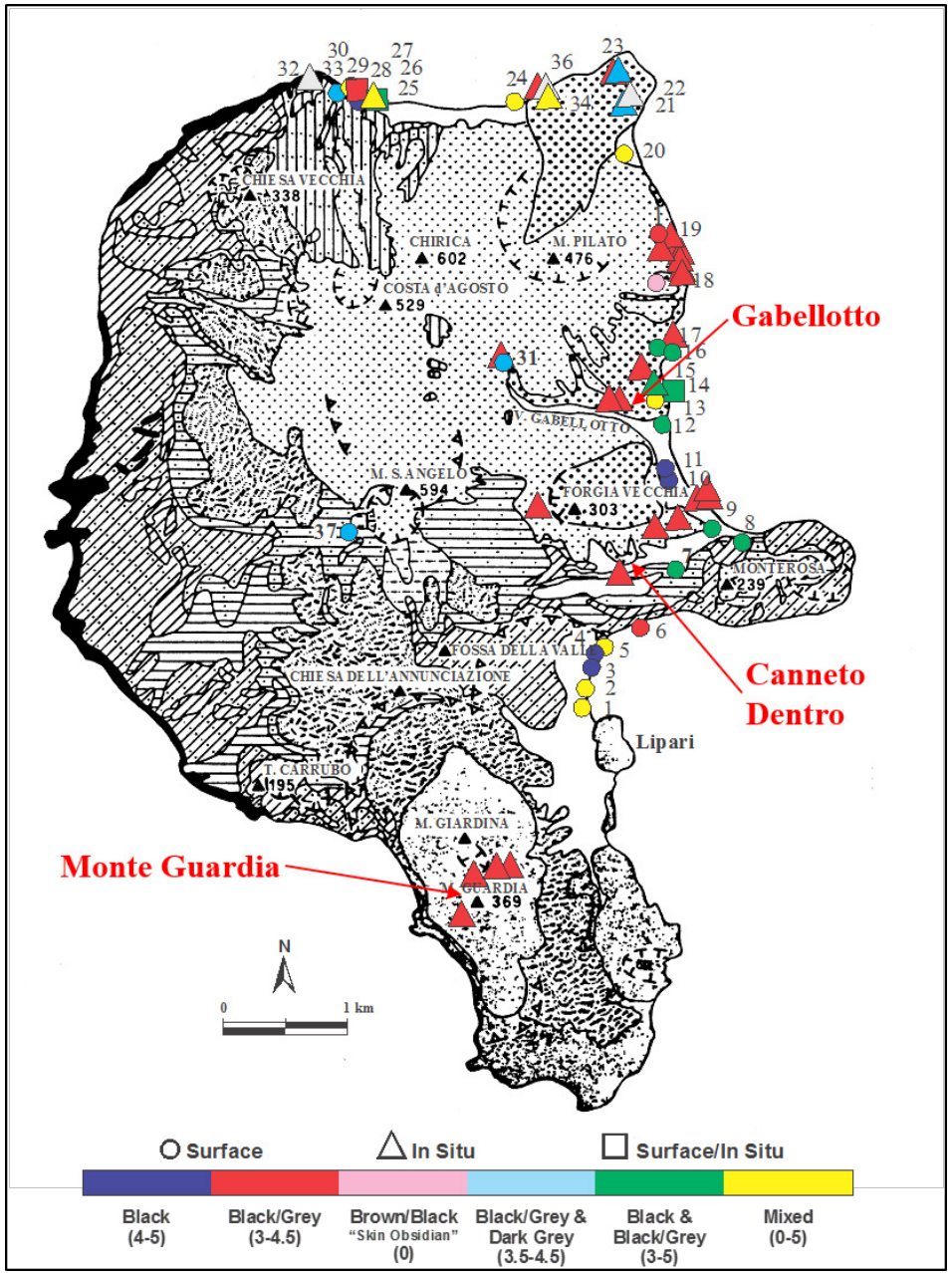

Figure 2. Lipari localities of geological samples collected.

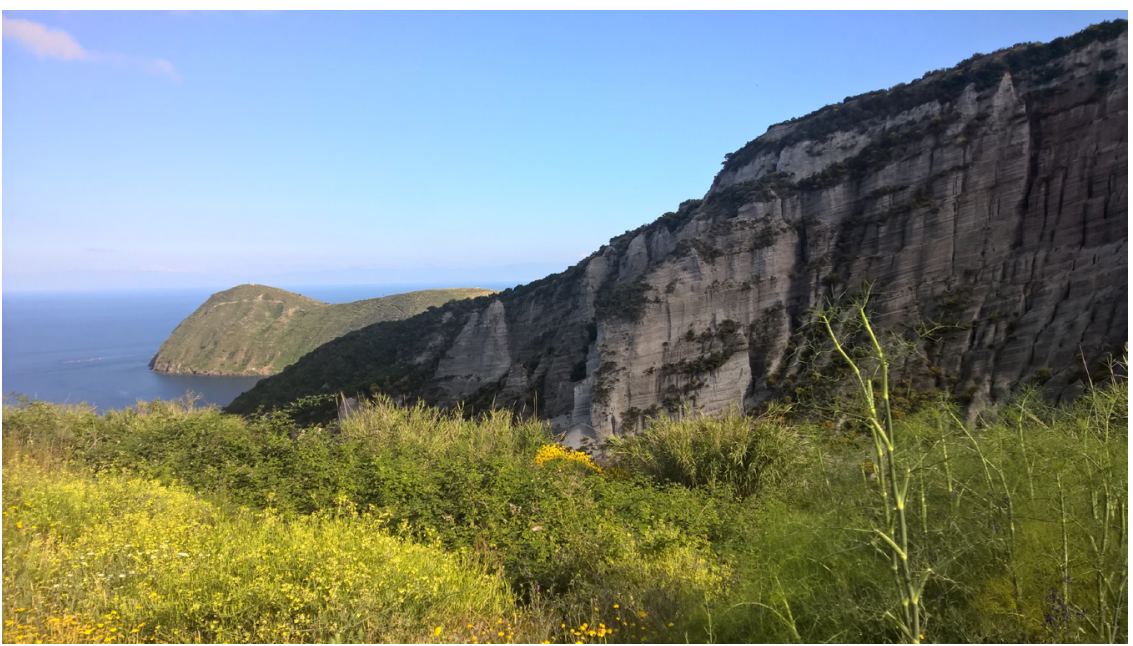

Figure 3. Picture of Gabellotto Gorge from the northwest. Monte Rosa in the background. 


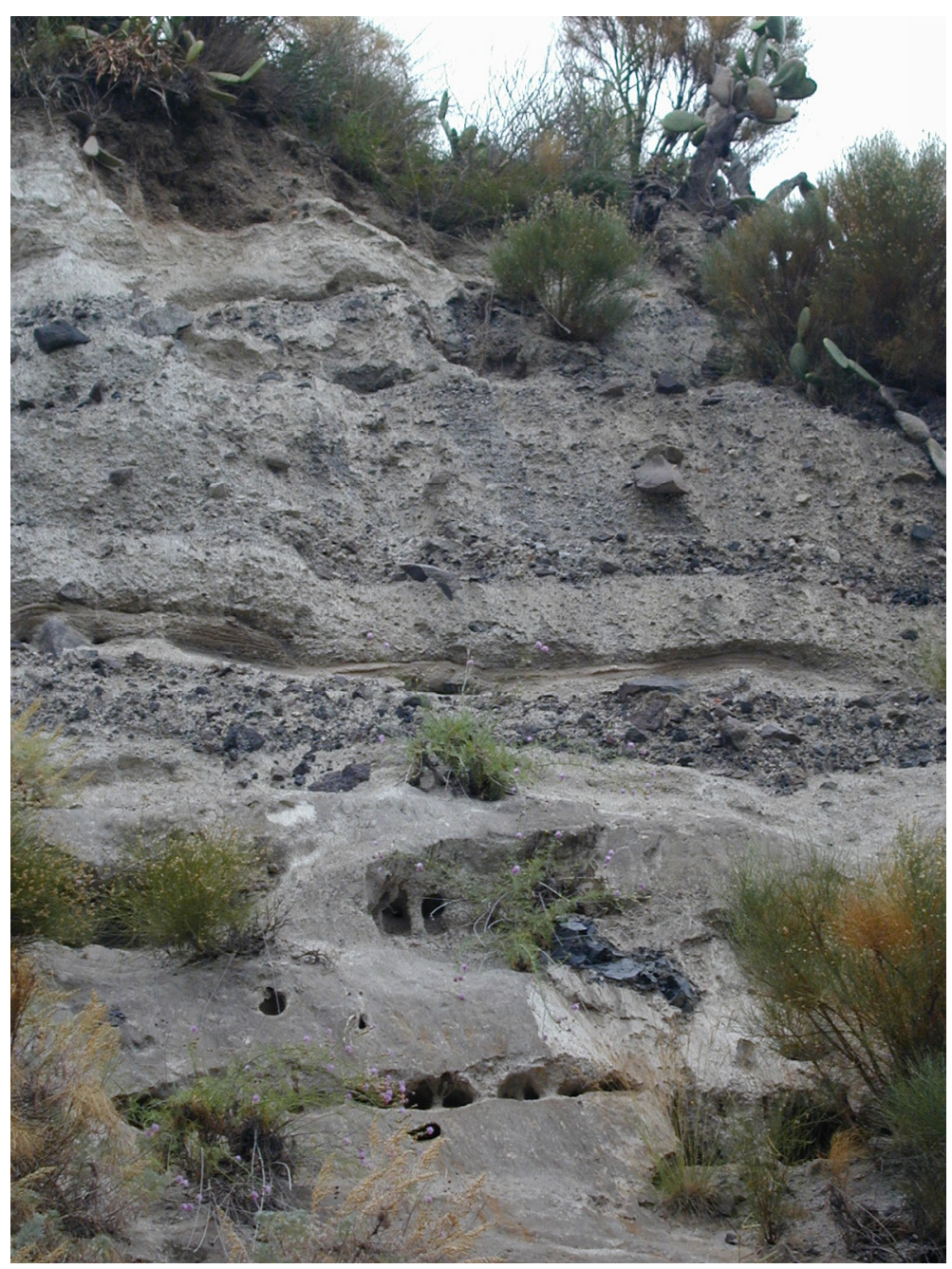

Figure 4. Picture of Gabellotto Gorge outcrop.

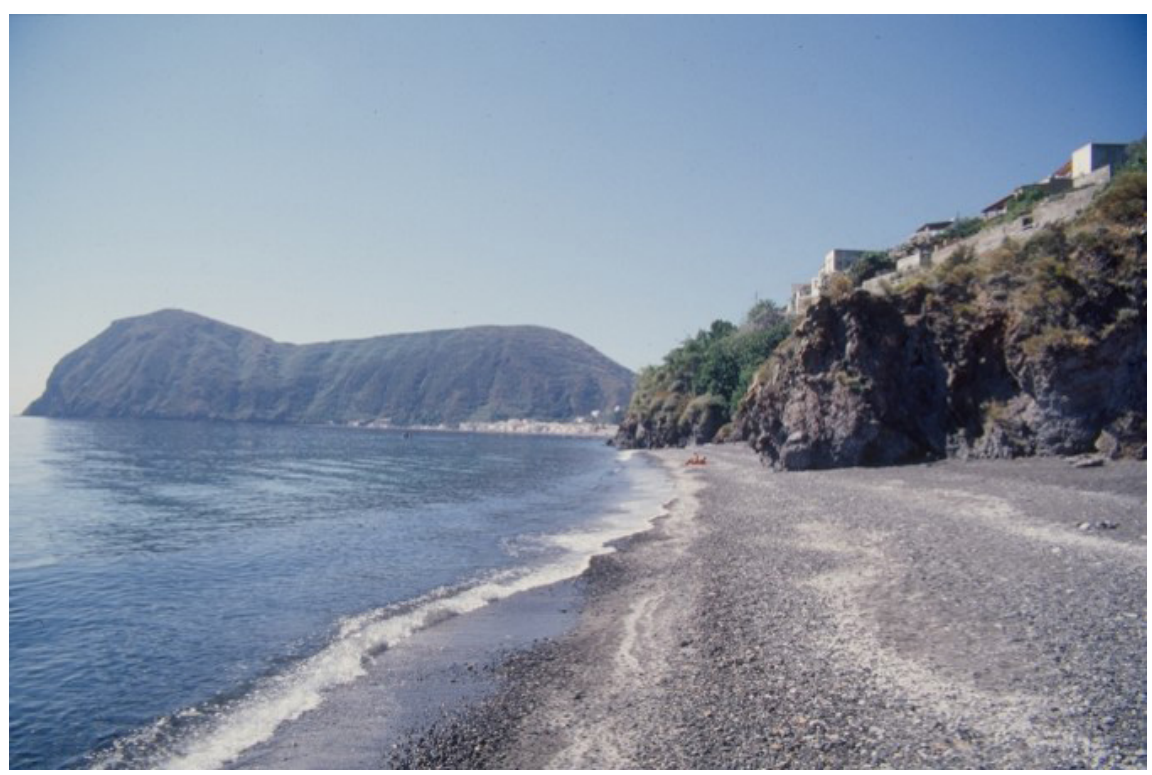

Figure 5. Lipari coast with obsidian. Picture from north with Monte Rosa in the background. 


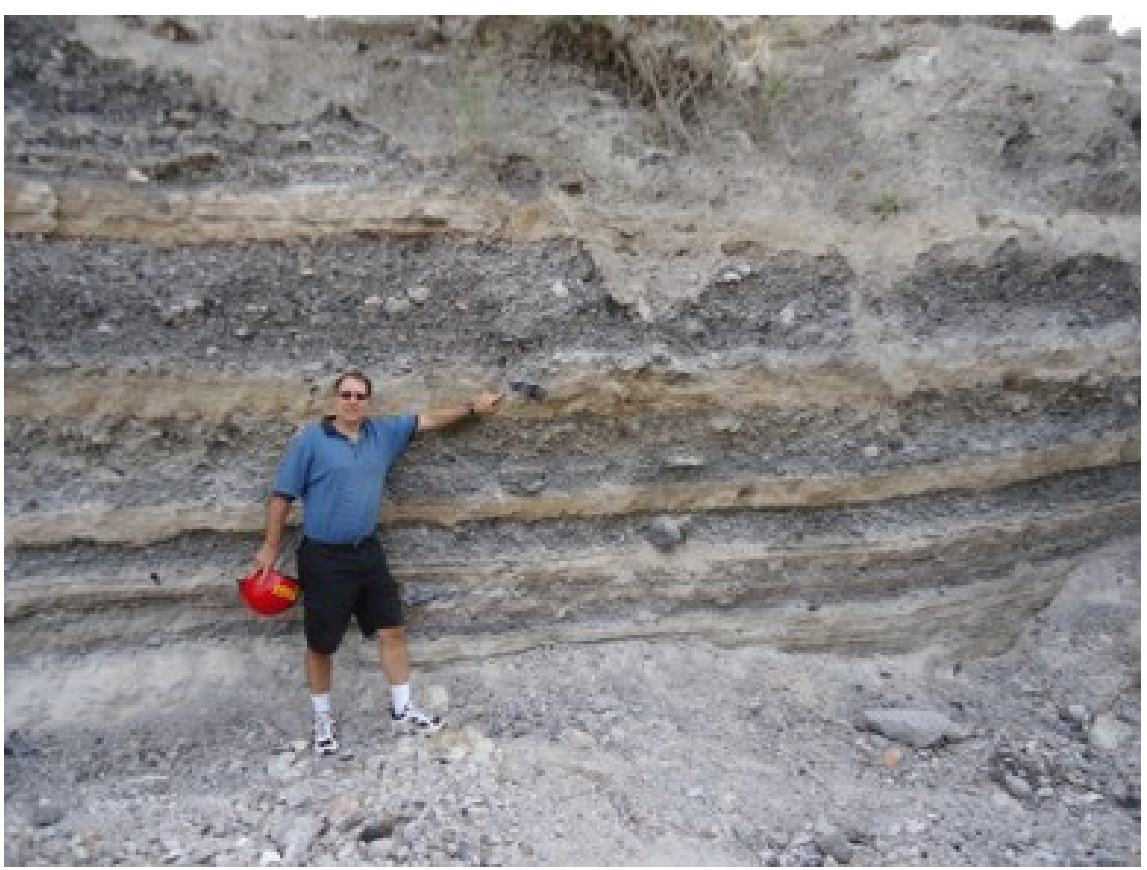

Figure 6. Obsidian deposits exposed by modern construction activities.

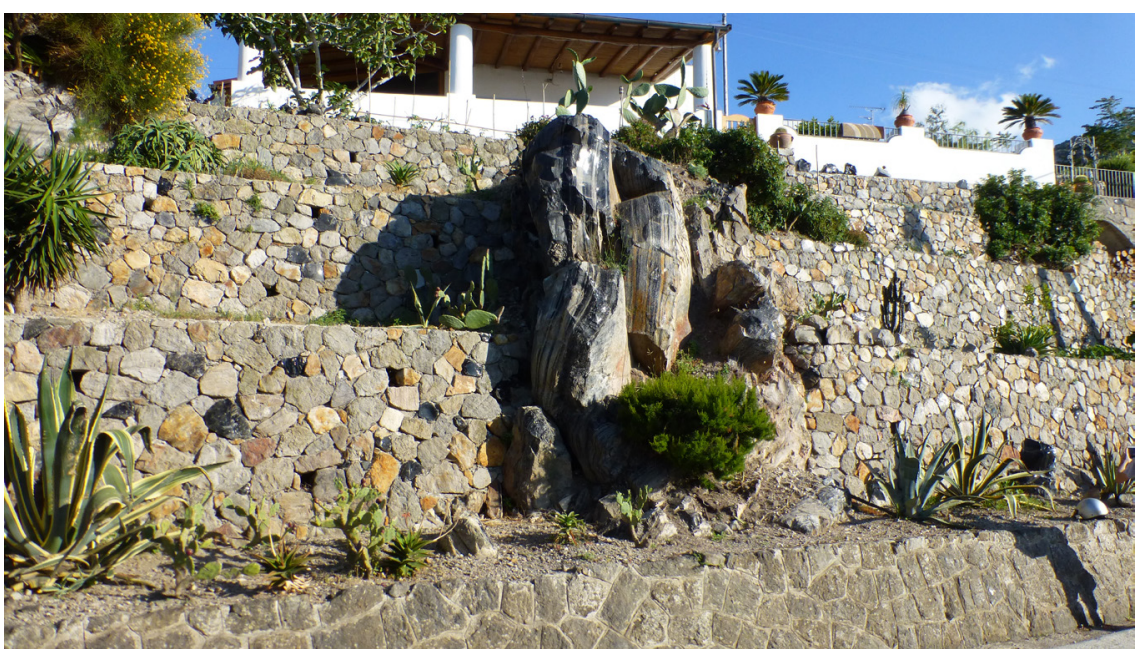

Figure 7. Obsidian block near Roche Rosse.

A detailed photographic record was taken along with field logs recording each locality, the quality, quantity, and size of the obsidian nodules collected as well as its geological depositional context, i.e., whether it was in an in situ or secondary deposit. Subsequently in the laboratory, the specimens were weighed and photographed digitally, and small sections of 1 gram each were removed with a diamond saw, ultrasonically cleaned, and later oven-dried in preparation for density measurements to be taken. The density was obtained by measuring the dry mass and the suspended wet weight in a water/PV wetting solution. When the density values are compared with those for the other central Mediterranean island sources, Lipari obsidian has the lowest and mostly can be differentiated from Palmarola and Sardinia (Figure 8). Lipari obsidian is often very glassy, while Pantelleria obsidian is much denser, and the least brittle.

Visual descriptions were made for obsidian, specifically transparency, luster, color, type and color of any inclusions or patterning, e.g., banding, mottling, or streaking that may have been present. Lipari obsidian has a wide range of transparency, from opaque to highly transparent, with those in the opaque 
category often having extensive phenocrysts. The luster is typically high, while all are in the dark gray-toblack range of color; there is significant variation in the color patterns, including uniform, banded, streaked, and mottled, but nearly all with a smooth texture. These varieties were used for producing obsidian cores and stone tools (Figures 9-10).

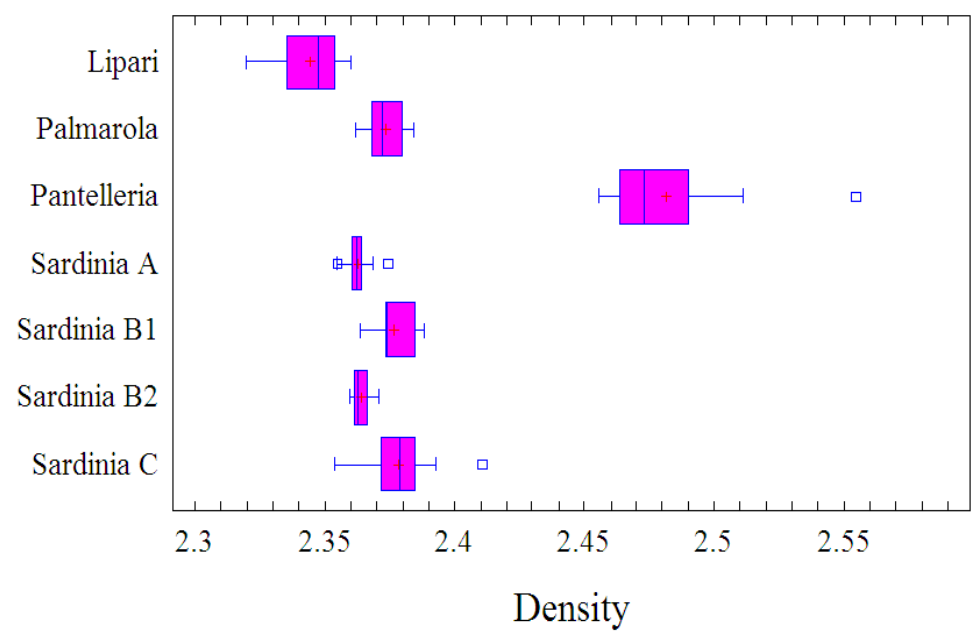

Figure 8. Box plot of density for central Mediterranean obsidian geological samples.

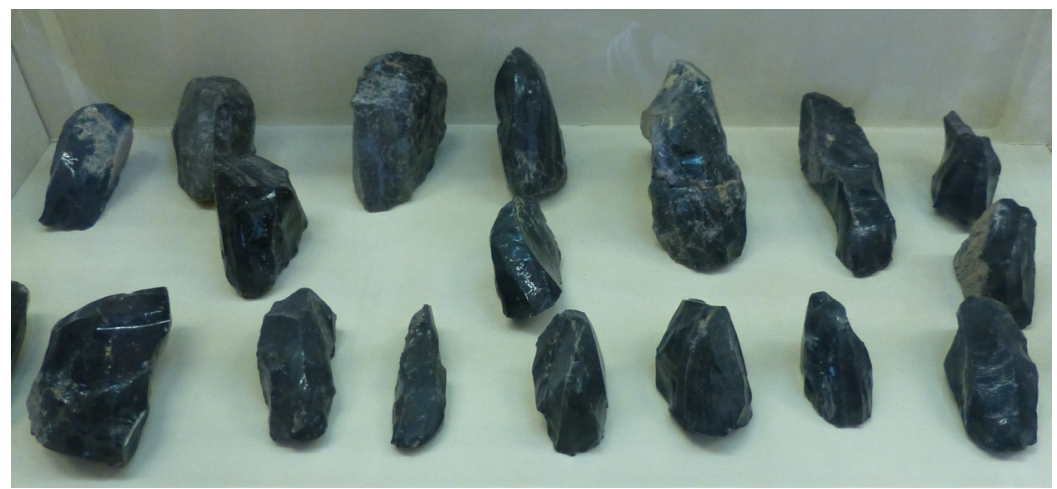

Figure 9. Selection of obsidian cores found on Lipari.

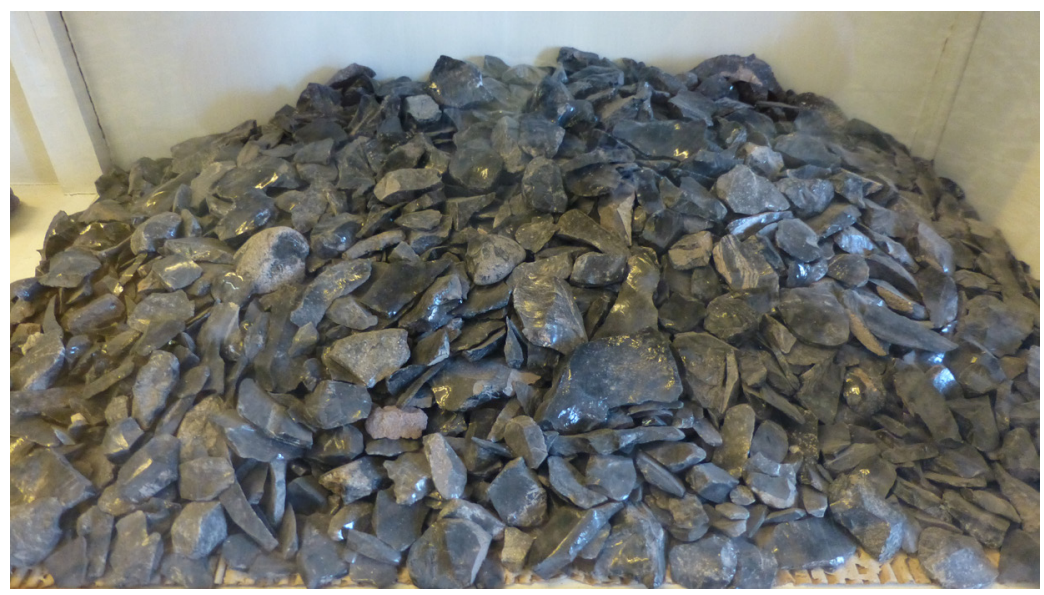

Figure 10. An obsidian assemblage from Lipari. 


\section{Obsidian Source Characterization}

Cann \& Renfrew (1964) first demonstrated that many of the European/Near Eastern obsidian sources could be differentiated based on their trace element composition (especially barium, zirconium, niobium and yttrium) as determined by optical emission spectroscopy, while earlier studies by Cornaggia Castiglioni et al. (1962, 1963) which used manganese and other major elements were promising in the Mediterranean but had some erroneous attributions. By the mid-1970s, the use of X-ray fluorescence spectrometry and instrumental neutron activation analysis were each shown to be quite successful in attributing artifacts to specific Mediterranean islands, and illustrating the long-distance distribution of artifacts from these sources in the neolithic (Hallam et al., 1976; Francaviglia, 1984). Since then, additional analytical methods have been successfully used, including major/minor element analyses using scanning electron microscopes (SEM) with energy-dispersive (ED) or wavelength dispersive (WD) spectrometers (Le Bourdonnec et al., 2006; Tykot, 1997), and trace element analyses using atomic absorption spectroscopy (AAS), inductively coupled plasma emission spectrometry (ICP-OES, ICP-AES) and mass spectrometry (ICP-MS), often with a laser (Barca et al., 2007; Tykot, 2002, 2004). While all of these methods have been used successfully, the size of archaeological research projects had been limited due to the accessibility, cost and destructive nature of most analytical methods. The $21^{\text {st }}$ century development of non-destructive XRF instruments, especially portable types, has changed that entirely with many thousands of artifacts from the central Mediterranean now tested (De Francesco et al., 2011; Le Bourdonnec, 2007; Pappalardo et al., 2013; Poupeau et al., 2009; Tykot 2017a, b).

It is important from an archaeological perspective to have detailed information on the actual location(s) where obsidian was obtained, and not just attribute artifacts to a general geological region or island. Elsewhere in the Mediterranean, attributing archaeological samples to specific island subsources already has been shown to be extremely important for understanding the actual acquisition of the raw materials, including the physical travel and transport involved; differences in the quantity, quality, and visual characteristics between different outcrops or subsources; and whether acquisition was done by local residents, perhaps with territorial control of access, or by visitors whether local or from elsewhere. For Monte Arci on Sardinia, it has been shown that the usage of obsidian from three subsources (SA, SB2, SC) changed over the course of the Neolithic (Tykot, 1997), while for Melos in the Aegean the subsources of Sta Nychia and Dhemenegaki were also used in different proportions with changes over time (Carter \& Kilikoglou, 2007).

The transport and distribution of obsidian found at mainland sites was complex, and involved at least three separate steps of travel: from island source locale over land to the coast, carried by people and possibly oxen; over water, in some kind of raft or vessel; and back on land from coast to archaeological site, perhaps with different people and/or oxen, especially if over lengthy distances.

\section{Lipari Obsidian Analysis}

A statistically significant selection of the approximately 1300 geological samples collected during the Lipari survey were initially analyzed by INAA, LA-ICP-MS, and ED-XRF at the Missouri University Research Reactor (Speakman et al., 2007). Many of the same samples were analyzed by the different methods. Details on the sample preparation and analysis by these instruments are provided in Appendix. Each of these analytical methods revealed elemental differences between Gabellotto Gorge and Canneto Dentro, as well as with the earlier Monte Guardia and later Forgia Vecchia and Rocche Rosse deposits (Tykot et al., 2006). There are also two chemical groups for Gabellotto Gorge, one for the north area and one in the base of the gorge.

Neutron activation analysis was conducted on 159 geological samples, including 39 of prehistoric age. The prehistoric Lipari obsidian subgroups of Monte Guardia, Gabellotto (base and north), and Canneto Dentro are distinguishable using several different trace elements, with clear differences for La, Ce, and Co (Figure 11). 


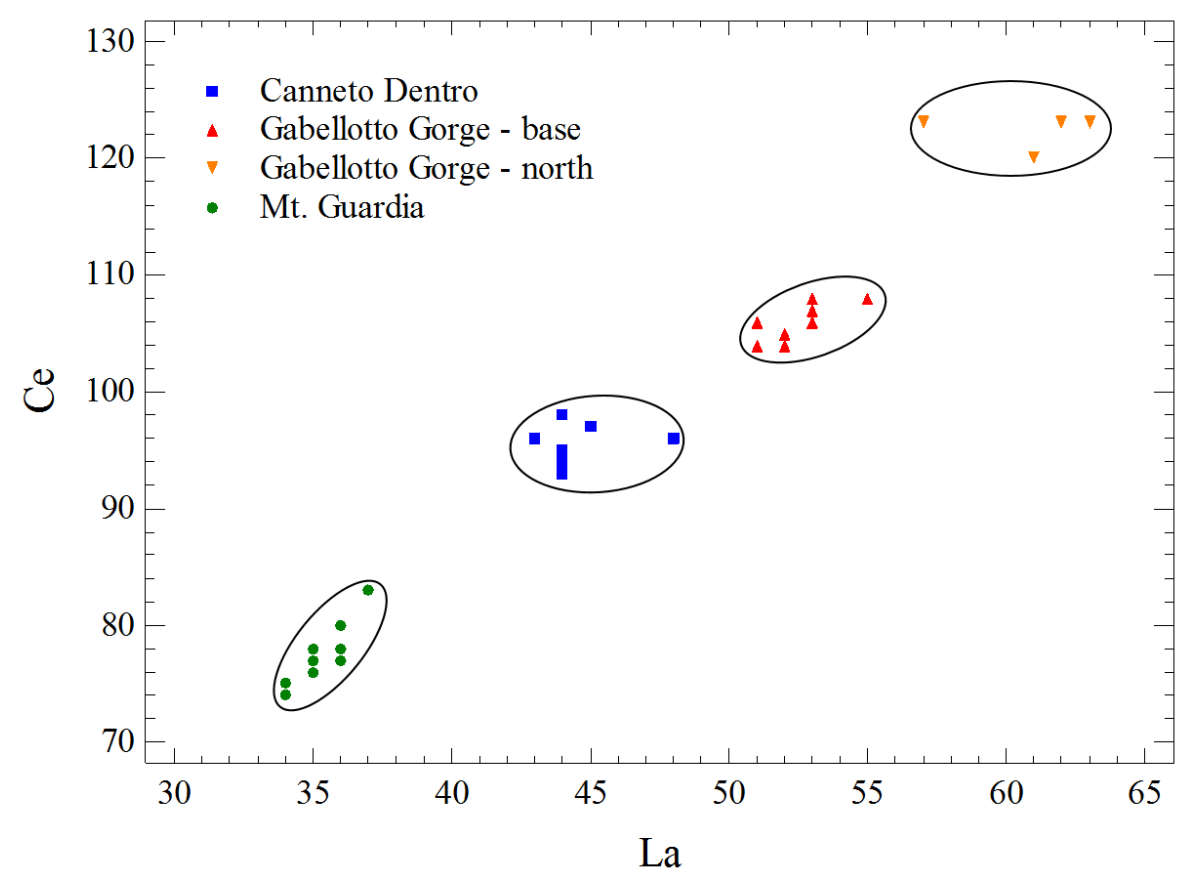

Figure 11. X-Y graph of Lipari subsources using INAA on trace elements lanthanum and cerium.

Laser ablation ICP mass spectrometry was performed on 213 geological samples, including 49 of prehistoric age. Multi-variate discriminant function statistical analysis clearly distinguishes not only the prehistoric subgroups of Monte Guardia, Gabellotto (base and north), and Canneto Dentro, but also the historic Forgia Vecchia and Rocche Rosse subsources (Figures 12-13).

Energy-dispersive X-ray fluorescence analysis was performed on 110 geological samples, with 20 of prehistoric age. While the ED-XRF is as successful as INAA and LA-ICP-MS in discriminating the Lipari subsources, subsequent non-destructive XRF analyses have been conducted with a portable model.

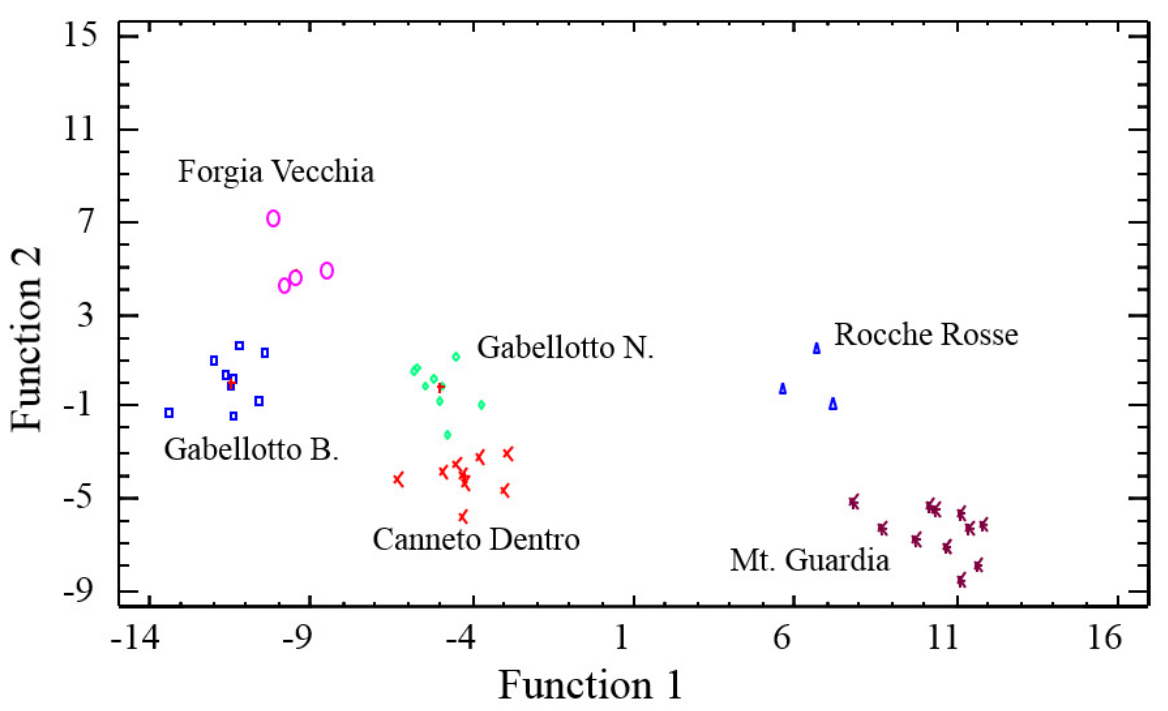

Figure 12. Discriminant function graph of prehistoric and historic Lipari subsources by LA-ICP-MS. 


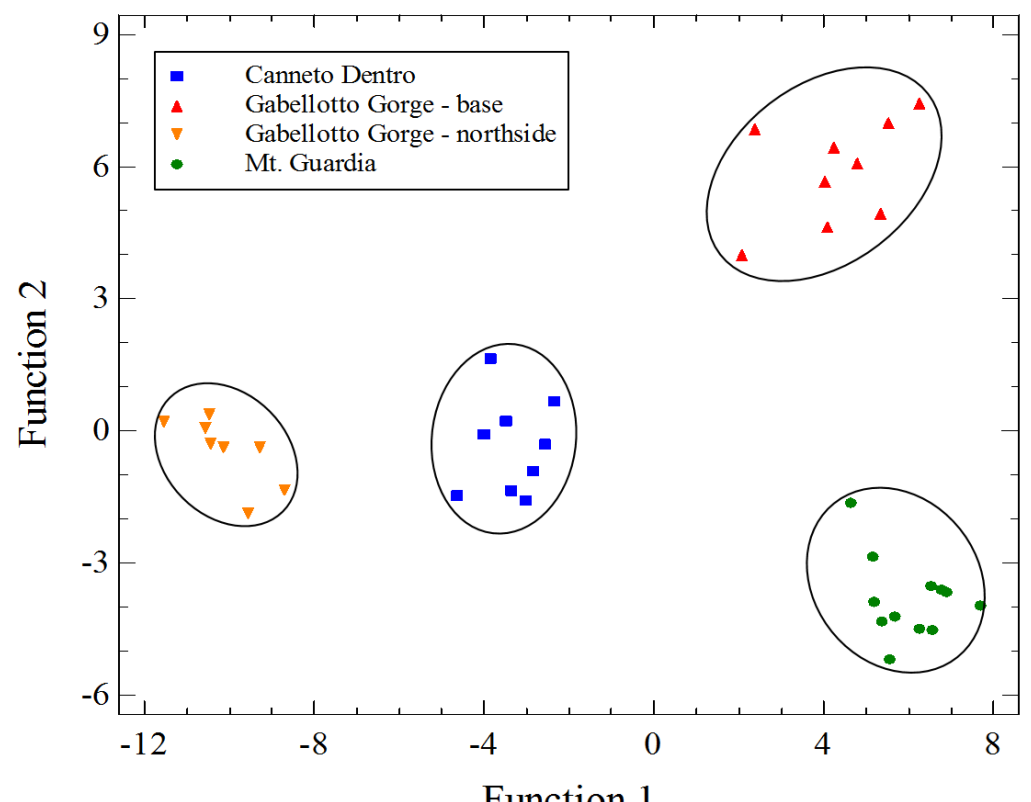

Function 1

Figure 13. Discriminant function graph of prehistoric Lipari subsources by LA-ICP-MS.

Over the past ten years, the pXRF analyses were conducted using different models of the Bruker Tracer, including the III-V+, III-SD, and Vi. The settings have remained fairly similar, using a Cu-Ti-Al filter to reduce the background and increase the precision of the K-alpha peaks for Fe through $\mathrm{Rb}$, while running at 40-50 kV and 10-35 $\mu \mathrm{A}$ for 180 to 30 seconds. In each case, the results are calibrated using a large number of obsidian standards provided by MURR (Missouri University Research Reactor) and run directly on each instrument (Tykot, 2017b). When using the pXRF, which produces quantitative data on fewer trace elements than the other methods, assignment of an artifact to a specific Lipari subsource is dependent mainly on the concentration of strontium, with the base of Gabellotto 20 ppm, the northern area of Gabelloto $\sim 30-35 \mathrm{ppm}$, and at Canneto Dentro $\sim 40-70 \mathrm{ppm}$. More than 60 prehistoric geological subsource samples have been tested by pXRF (Figure 14).

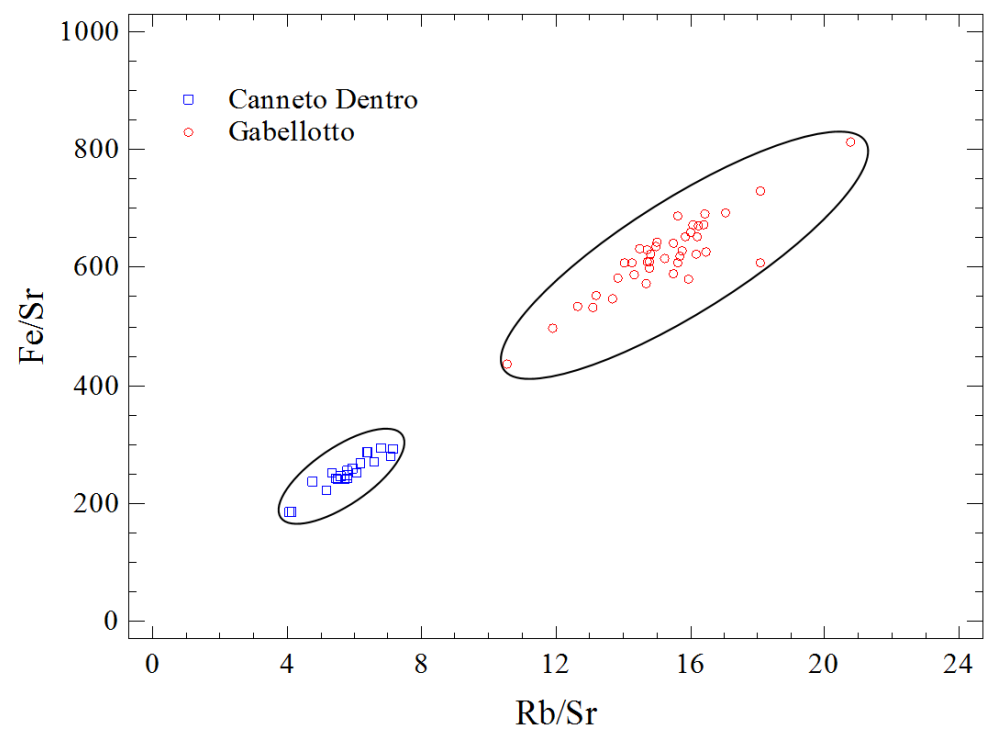

Figure 14. Element ratios for Canneto Dentro and Gabellotto Gorge by pXRF. 


\section{Discussion}

Many thousands of prehistoric obsidian artifacts from central Mediterranean sites in Sicily, Malta, Ustica, Croatia, and throughout peninsular Italy, as well as at some sites in Corsica and southern France, have been analyzed and assigned to Lipari (Tykot, 2017a; Freund, 2018) (Figure 15). The predominance of Lipari obsidian in lithic assemblages in Sicily and Calabria is of no surprise given their modest distances from this Aeolian island and the apparent regularity of sea travel and mobility during the Neolithic in this region (see also Ammerman, 1985; Robb \& Farr, 2005). It is only about $20 \mathrm{~km}$ open water from Lipari to the tip of Milazzo in northern Sicily, while it appears that regular sea travel over much greater distances occurred regularly by the beginning of the neolithic, with settlements and domestic animals on Malta (80 km), Ustica $(52 \mathrm{~km})$, and many other islands in the Mediterranean. In general, it appears that obsidian cores were produced on Lipari and regularly brought to Sicily and Calabria where they were used to produce blades.

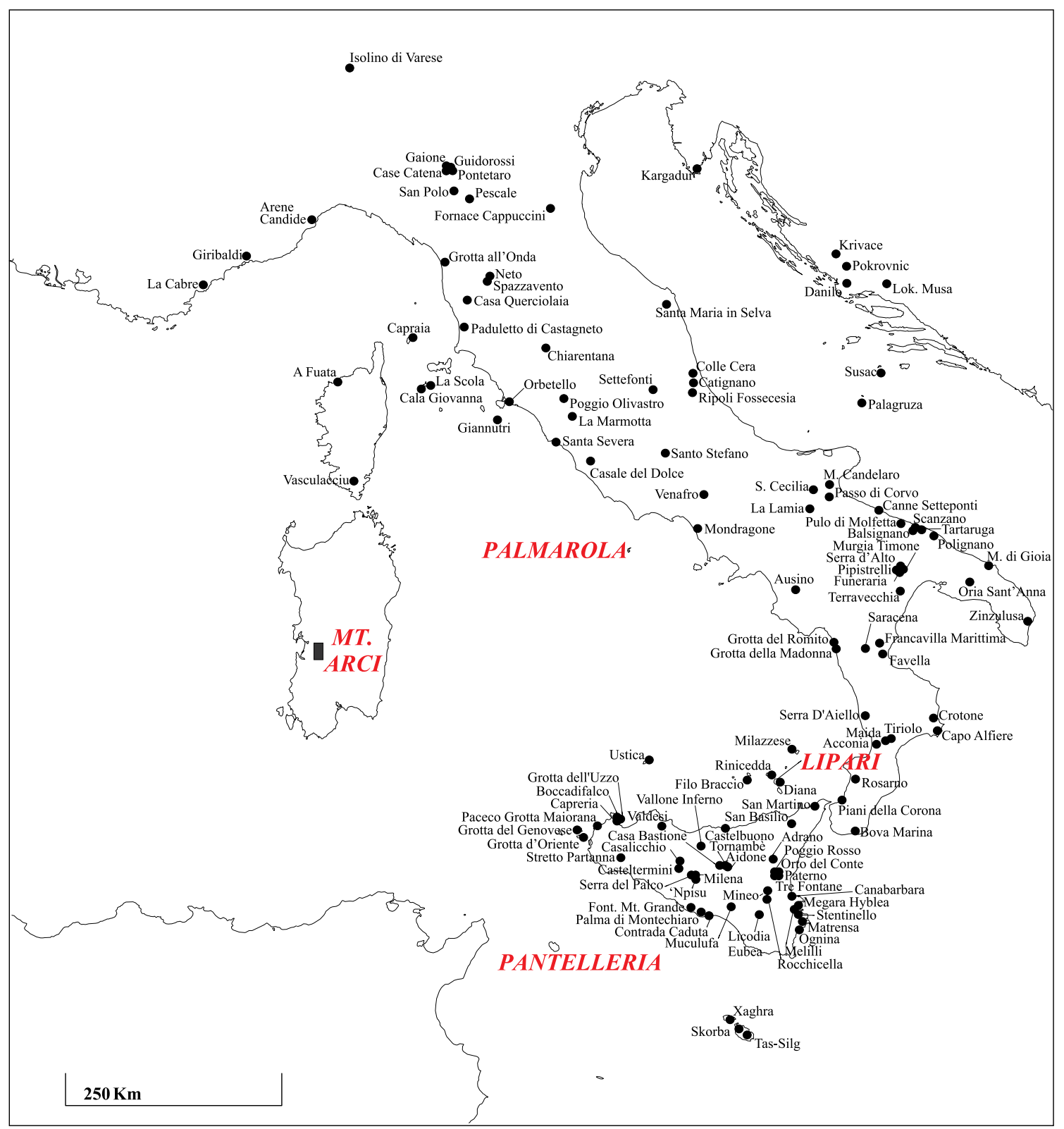

Figure 15. Sites with Lipari obsidian and $\geq 10$ artifacts analysed. 
The distribution during the Neolithic of Lipari obsidian in small quantities as far as southern France has also been known for some time, and this may be thought to have been exotic items that made their way to the fringes of obsidian distribution (Tykot, 2011). Significant quantities of Lipari obsidian, however, have been found on the Croatian side of the Adriatic Sea (Tykot, 2014), and at several sites in central and northern Italy, including Poggio Olivastro, Pescale, and four near Parma (Tykot et al., 2018), expanding considerably the geographic area in which obsidian regularly was distributed during the Neolithic, perhaps to some inland sites which served as centers for redistribution.

Important to note is that it appears from these thousands of analyses of obsidian artifacts that came from Lipari that the major source locality was the base of Gabellotto Gorge. Only very small percentages from the north area of Gabellotto, and from Canneto Dentro, were utilized in the past. Low percentages of Canneto Dentro obsidian artifacts have been identified at many sites in Sicily, but none at all identified in Malta, or on Ustica. For peninsular Italy, Canneto Dentro obsidian has been identified at 6 different sites in Calabria and Campania, but only 8 artifacts in total and $0.3 \%$ of the total number of the obsidian artifacts from these regions assigned to Lipari. Further interpretation of these data, with comparisons between different chronological phases of the Neolithic, may suggest that this is related to the development of territorial control and organized production within Lipari.

\section{Conclusions}

While our recognition of the long-distance distribution of obsidian from Lipari has become quite wellestablished, there had been several other important questions that needed to be addressed, including how and where the obsidian was actually obtained on Lipari, and whether that may have changed over time as has been shown for the Monte Arci subsources on Sardinia (Tykot, 1996). In this study, the results of the detailed collection and elemental analysis of geological obsidian samples throughout the island of Lipari demonstrated that specific outcrop areas of obsidian available in prehistoric times could be distinguished from each other, as well as from the historic eruptions, using rapid non-destructive analyses with a portable $\mathrm{XRF}$, as well as by INAA and LA-ICP-MS.

The analyses of many thousands of artifacts from sites throughout Italy and neighboring countries has revealed none attributed to Monte Guardia, apparently due to the only small-size geological pieces found there, while the low percentage of artifacts attributed to Canneto Dentro was expected given its quite modest exposed geographic area relative to the large Gabellotto Gorge area still accessible today. Nevertheless, the infrequent apparent use of Canneto Dentro obsidian on and off Lipari may enlighten our understanding of the chaîne opératoire of selection, production, and distribution established in the Early Neolithic and how that may have changed over the following several thousand years in the central Mediterranean. The assessment of whether pre-formed cores were only produced on Lipari, or natural blocks were transported to Sicily or mainland Italy, may be related to who was involved in the initial acquisition, i.e. island residents or irregular visitors, and the overall purpose and frequency of their maritime travels. There is no question that the quantity of obsidian working evident by the Middle Neolithic at Castellaro Vecchio indicates major production on Lipari for export.

Understanding the role of obsidian in the development of cultural and economic complexity on the island of Lipari is central to our reconstruction of the social dynamics of a broader regional exchange network in the central Mediterranean, especially that in Sicily, nearby islands, and southern peninsular Italy during the Neolithic. The identification of Lipari obsidian artifacts at more than 200 archaeological sites in the central Mediterranean is important for understanding patterns of culture contact, maritime capabilities and levels of socio-economic organization as they may have changed over the course of the Neolithic period. Obsidian also acts as a proxy for materials less visible in the archaeological record when reconstructing contact networks. Being able to distinguish between obsidian subsources, and whether certain patterns were characteristic of specific time periods, provides some insight into the cultural, economic, and political complexity of prehistoric Lipari. 
Note: A complete database of the geological samples, representing both prehistoric and historic time periods, and including GPS location, size and weight measurements, detailed visual description, and analytical data is available upon request.

Acknowledgments: The detailed survey of Lipari and analyses of geological obsidian were supported by NSF grant BCS-0075535, and involved several students and colleagues including Lisa Beyer, Maria Clara Martinelli, Teddi Setzer, and Barbara Vargo. Thanks are due to Michael Glascock and Jeff Speakman for the analyses conducted at MURR of the geological samples, and more recently to Kyle Freund and Andrea Vianello for assisting with the technotypological descriptions and non-destructive analyses by pXRF of thousands of obsidian artifacts from many different archaeological sites. I very much appreciate Andrea's efforts to obtain permissions to conduct these analyses at many different museums and storage facilities in Sicily and southern Italy, and the officials involved in granting those permissions. The Museo Archeologico Luigi Bernabò Brea on Lipari provided authorization to sample the artifacts in its extensive collections, while also providing workspace for analyses and allowing the publication of Figures 9 and 10 (obsidian from their collections).

\section{References}

Ammerman, A.J. (1985). The Acconia Survey: Neolithic Settlement and the Obsidian Trade. Lonon: Institute of Archaeology, University of London.

Arias-Radi, G., Bigazzi, G., \& Bonadonna, F. (1972). Le tracce di fissione: Un metodo per lo studio delle vie di commercio dell'ossidiana. Origini: Preistoria e Protostoria delle civiltà antiche, 6, 155-169.

Arias, C., Bigazzi, G., Bonadonna, F. P., Cipolloni, M., Hadler, J. C., Lattes, C. M. G., \& Radi, G. (1984). Fission track dating in archaeology, a useful application. In P. L. Parrini (Ed.), Scientific methodologies applied to works of art (pp. 151-159).

Barca, B., De Francesco, A.M., \& Crisci, G.M. (2007). Application of Laser Ablation ICP-MS for characterization of obsidian fragments from peri-Tyrrhenian area. Journal of Cultural Heritage, 8(2), 141-150.

Bernabò Brea, L., \& Cavalier, M. (1957). La stazione stentinelliana del Castellaro Vecchio presso Quattropani (Lipari). Bullettino di Paletnologia Italiana, 66, 97-151.

Bernabò Brea, L., \& Cavalier, M. (1960). La stazione preistorica della Contrada Diana e la necropoli protostorica di Lipari. Meligunis Lipara I. Flaccovio, Palermo.

Bigazzi, G., \& Bonadonna, F. (1973). Fission Tracking Dating of the Obsidian of Lipari Island (Italy). Nature, 242, 322-323.

Cann, J.R., \& C. Renfrew. (1964). The characterization of obsidian and its application to the Mediterranean region. Proceedings of the Prehistoric Society, 30, 111-33.

Carter, T., \& Kilikoglou, V. (2007). From Reactor to Royalty? Aegean and Anatolian Obsidians from Quartier Mu, Malia (Crete). Journal of Mediterranean Archaeology, 20.1, 115-143.

Cornaggia Castiglioni, O., Fussi, F., \& D’Agnolo, M. (1962). Indagini sulla provenienza dell'ossidiana in uso nelle industrie preistoriche italiane. Atti della Società Italiana di Scienze Naturali e del Museo Civico di Storia Naturale in Milano, 101, 12-19.

Cornaggia Castiglioni, O., Fussi, F., \& D’Agnolo, M. (1963). Indagini sulla provenienza dell'ossidiana utilizzata nelle industrie preistoriche del Mediterraneo occidentale. Atti della Società Italiana di Scienze Naturali e del Museo Civico di Storia Naturale in Milano, 102, 310-22.

Crisci, G.M., De Rosa, R., Esperanca, S., Mazzuoli, R., \& Sonnino, M. (1991). Temporal evolution of a three component system: the island of Lipari (Aeolian Arc, southern Italy). Bulletin of Volcanology, 53, 207-221.

Crisci, G.M., Ricq-de Bouard, M., Lanzaframe, U., \& De Francesco, A.M. (1994). Les obsidiennes du midi de la France. Gallia Preistoire, 36, 299-327.

De Francesco, A.M., Bocci, \& G. M. Crisci. (2011). Non-destructive applications of wavelength XRF in obsidian studies in X-ray fluorescence spectrometry (XRF) in geoarchaeology. In M. S. Shackley (Ed.), X-Ray Fluorescence Spectrometry (XRF) in Geoarchaeology. (pp. 81-107). New York: Springer.

Forni, F., Lucchi, F., Peccerillo, A., Tranne, C.A., Rossi, P.L., \& Frezzotti, M.L. (2013). Stratigraphy and geological evolution of the Lipari volcanic complex (cental Aeolian archipelago). In F. Lucchi, A. Peccerillo, J. Keller, CA. Tranne, P.L. Rossi (Eds.), The Aeolian Islands Volcanoes. (pp. 213-279). London: Geological Society.

Francaviglia, V.M. (1984). Characterization of Mediterranean obsidian sources by classical petrochemical methods. Preistoria Alpina, 20, 311-332.

Freund, K.P. (2018). A long-term perspective on the exploitation of Lipari obsidian in central Mediterranean prehistory. Quaternary International, 468, 109-120. 
Gioncada, A., Mazzuoli, R., Bisson, M., \& Pareschi, M.T. (2003). Petrology of volcanic products younger than 42 ka on the Lipari-Vulcano complex (Aeolian Islands, Italy): an example of volcanism controlled by tectonics. Journal of Volcanology and Geothermal Research, 122, 191-220.

Gratuze, B., Blet-Lemarquand, M., \& Barrandon, J.N. (2001). Mass spectrometry with laser sampling: A new tool to characterize archaeological materials. Journal of Radioanalytical and Nuclear Chemistry, 247 (3), 645-656.

Hallam, B.R., Warren, S.E., \& Renfrew, C. (1976). Obsidian in the western Mediterranean: chacterisation by neutron activation analysis and optical emission spectroscopy. Proceedings of the Prehistoric Society, 42, 85-110.

Keller, J. (1970). Datierung der Obsidiane und Bimstuffe von Lipari. Neues Jahrbuch fur Geologie und Palaontologie, Monatshefte, 1, 90-101.

Le Bourdonnec, F.-X. (2007). Aspects archéométriques de la circulation de l'obsidienne préhistorique: Développements analytiques et applications en Corse, Sardaigne et Éthiopie. PhD dissertation, Université Michel de Montaigne Bordeaux 3, France.

Le Bourdonnec, F.-X., Poupeau, G., \& Luglie, C. (2006). SEM-EDS analysis of western Mediterranean obsidians: a new tool for Neolithic provenance studies. C. R. Geoscience, 338, 1150-1157.

Martinelli, M.C. (2016). Updates on the cultural and chronological framework of the prehistory and protohistory of the Aeolian Islands: from the first settlement to the end of the villages. In Cazzella, A., Guidi, A., Nomi, F. (eds.) Convegno di studi in memoria di Giorgio Buchner "Ubi minor.. le isole minori del Mediterraneo centrale dal Neolitico ai primi contatti coloniali”, Capri - Anacapri - Ischia 27-29 ottobre 2013, Scienze dell'Antichità, Roma, 263-279.

Martinelli, M.C., Tykot, R.H., Vianello, A. (2019). Lipari (Aeolian Islands) Obsidian in the Late Neolithic. Artifacts, Supply and Function. Open Archaeology, 5, 46-64.

Pappalardo, L., Romano, F. P., Bracchitta, D., Massimino, A., Palio, O., \& Rizzo, F. (2013). Obsidian provenance determination using the beam stability controlled BSC-XRF and the PIXE-alpha portable spectrometers of the LANDIS laboratory: the case of Via Capuana settlement in Licodia Eubea (Sicily). Journal of Geophysics and Engineering, 10, 1-12.

Pichler, H. (1980). The Island of Lipari. Rendiconti Societa Italiana di Mineralogia e Petrologia, 36, 415-440.

Poupeau, G., Le Bourdonnec, F.-X., Dubernet, S., \& Delerue, S. (2009). Instrumental methods of obsidian characterization and prehistoric obsidian provenance studies: The current status. In S. Farina, L. Eigeland, L.-J. Costa (Eds.), Non-Flint Raw Material Use in Prehistory: Old prejudices and new directions. Proceedings of the XV World Congress (Lisbon, 4-9 September 2006). (pp. 35-42). Oxford: Archaeopress.

Robb, J.E., \& Farr, R.H. (2005). Substances in motion: neolithic Mediterranean “Trade”. In E. Blake, \& A. B. Knapp (Eds.), The Archaeology of Mediterranean Prehistory. (pp. 24-46). Chichester, GB: Blackwell Publishing Ltd.

Siani, G., Sulpizio, R., Paterne, M., \& Sbrana, A. (2004) Tephrostratigraphy study for the last 18,000 14C years in a deep-sea sediment sequence for the South Adriatic. Quaternary Science Reviews, 23, 2485-2500.

Speakman, R.J., Glascock, M.D., Tykot, R.H, Descantes, C., Thatcher, J.J., Skinner, C.E., \& Lienhop, K.M. (2007). Selected Applications of Laser Ablation Inductively Coupled Plasma-Mass Spectrometry Archaeological Research. In M.D. Glascock, R.J. Speakman \& R.S. Popelka-Filcoff (eds.), Archaeological Chemistry: Analytical Techniques and Archaeological Interpretation. ACS Symposium Series, 968, 275-296. Washington, DC: American Chemical Society.

Tykot, R.H. (1996). Obsidian Procurement and Distribution in the Central and Western Mediterranean. Journal of Mediterranean Archaeology, 9(1), 39-82.

Tykot, R.H. (1997). Characterization of the Monte Arci (Sardinia) obsidian sources. Journal of Archaeological Science, 24, 467-479.

Tykot, R.H. (2002). Chemical fingerprinting and source-tracing of obsidian: The central Mediterranean trade in black gold. Accounts of Chemical Research, 35, 618-627.

Tykot, R.H. (2004). Scientific methods and applications to archaeological provenance studies. In M. Martini, M. Milazzo, M. Piacentini (Eds.), Physics Methods in Archaeometry. Proceedings of the International School of Physics "Enrico Fermi” Course CLIV. (pp. 407-432). Bologna, Italy: Società Italiana di Fisica.

Tykot, R.H. (2011). Obsidian finds on the fringes of the central Mediterranean: Exotic or eccentric exchange? In A. Vianello (Ed.), Exotica in the Prehistoric Mediterranean. (pp. 33-44). Oxbow Books.

Tykot, R.H. (2014). Obsidian use and trade in the Adriatic. In P. Visentini and E. Podrug (Eds.), The Adriatic, a sea without borders: communication routes of populations in 6000 BC. (pp. 171-181, 224-225). Civici Musei di Udine, Museo Friulano di Storia Naturale.

Tykot, R.H. (2017a). Obsidian Studies in the Prehistoric Central Mediterranean: After 50 Years, What Have We Learned and What Still Needs to Be Done? Open Archaeology, 3, 264-278.

Tykot, R.H. (2017b). A Decade of Portable (Hand-Held) X-Ray Fluorescence Spectrometer Analysis of Obsidian in the Mediterranean: Many Advantages and Few Limitations. MRS Advances, 2(33-34), 1769-1784.

Tykot, R.H., Freund, K.P., \& Vianello, A. (2013). Source analysis of prehistoric obsidian artifacts in Sicily (Italy) using pXRF. In R.A. Armitage, J.H. Burton (Eds.), Archaeological Chemistry VIII. ACS Symposium Series, 1147, 195-210.

Tykot, R.H., Freund, K.P., \& Vianello, A. (2018). Obsidian Distribution in the Western Mediterranean and the Spread of the Neolithic Package: A Chronological and Geographical Comparison. $24^{\text {th }}$ EAA Annual Meeting: Reflecting Futures (Barcelona, 2018) - Abstract Book, 2, 1116. 
Tykot, R.H., lovino, M.R., Martinelli, M.C., \& Beyer, L. (2006). Ossidiana da Lipari: le fonti, la distribuzione, la tipologia e le tracce d'usura. Atti del XXXIX Riunione Scientifica dell'Istituto Italiano di Preistoria e Protostoria: Materie prime e scambi nella preistoria italiana, Firenze, 25-27 November 2004. (pp. 592-597). Firenze.

Wagner, G.A., Storzer, D., \& Keller, J. (1976). Spaltspurendatierung Quartarer Gesteinsglaser aus dem Mittelmeerraum. Neues Jahsbuch for Mineralogie Monatslefle, 1976(2), 84-94.

Zanchetta, G., Sulpizio, R., Roberts, N., Cioni, R., Eastwood, W.J., Siani, G., Caron, B., Paterne, M., \& Santacroce, R. (2011). Tephrostratigraphy, chronology and climatic events of the Mediterranean basin during the Holocene: An overview. The Holocene, 21(1), 33-52. 


\section{Appendix. Instrumental Analyses}

\section{Analysis by INAA at MURR}

The obsidian samples were crushed to create a number of interior fragments (approx. 25-50 mg in size). The fragments were inspected under a magnifier to eliminate those with crush fractures, metallic streaks, etc. Two subsamples were prepared for INAA short and long irradiations. The first sample $(\sim 100 \mathrm{mg})$ was placed into a clean polyethylene vial, while the second sample (250-300 mg) was placed into a high-purity quartz vial. The short irradiation samples were sequentially irradiated for five seconds each in a neutron flux of $8 \times 1013$ neutrons $\mathrm{cm}-2 \mathrm{~s}-1$ and then decayed for 25 minutes before being counted for 12 minutes with a high-purity germanium (HPGe) detector. The short-lived elements $\mathrm{Ba}, \mathrm{Cl}, \mathrm{Dy}, \mathrm{K}, \mathrm{Mn}$ and $\mathrm{Na}$ were measured in most samples. The long irradiation samples were irradiated in bundles of 30-35 samples each for 70 hours in a neutron flux of $5 \times 1013$ neutrons cm-2 s-1. After decaying for about eight days, the long irradiation samples were loaded on a sample changer where they were counted for 2,000 seconds each to measure the medium-lived elements $\mathrm{Ba}, \mathrm{La}, \mathrm{Lu}, \mathrm{Nd}, \mathrm{Sm}, \mathrm{U}$, and $\mathrm{Yb}$. In most cases, the value for Ba determined from long irradiation was superior to that measured by short irradiation. Three weeks afterwards the long irradiation samples were counted again for 10,000 seconds to measure the long-lived elements $\mathrm{Ce}, \mathrm{Co}, \mathrm{Cs}, \mathrm{Eu}, \mathrm{Fe}, \mathrm{Hf}$, $\mathrm{Rb}, \mathrm{Sb}, \mathrm{Sc}, \mathrm{Sr}, \mathrm{Ta}, \mathrm{Tb}, \mathrm{Th}, \mathrm{Zn}$ and Zr. Standards made from SRM-278 Obsidian Rock and SRM-1633a were similarly prepared and irradiated for calibration and quality control of the analytical data.

Table 1. INAA analyses of Lipari subsources.

\begin{tabular}{|c|c|c|c|c|c|c|c|c|c|c|c|c|c|c|c|c|c|c|c|c|c|}
\hline USF \# & Area & Sc & $\mathrm{Fe}$ & $\mathrm{Zn}$ & $\mathbf{R b}$ & $\mathrm{Sr}$ & $\mathrm{Zr}$ & $\mathbf{S b}$ & Cs & $\mathrm{Ba}$ & La & $\mathrm{Ce}$ & Nd & $\mathrm{Sm}$ & $\mathrm{Eu}$ & Tb & $\mathbf{Y b}$ & Lu & $\mathrm{Ta}$ & Th & $\mathbf{U}$ \\
\hline 4560 & Mt. Guardia & 0,93 & 9939 & 0,1949 & 280 & 0 & 217 & 0,93 & 315,0 & 054 & 35 & 77 & 29 & 7,5 & 0,11 & 11,05 & 54,0 & $0,785,5$ & 2,20 & 039 & 12,0 \\
\hline 4565 & Mt. Guardia & 0,93 & 9986 & 0,2049 & 286 & 0 & 218 & 0,91 & 15,1 & 142 & 35 & 76 & 31 & 7,6 & 0,11 & 11,05 & 54,0 & $0,765,5$ & 2,24 & 439 & 11,9 \\
\hline 4574 & Mt. Guardia & 1,06 & 10301 & 0,2252 & 285 & 0 & 217 & 0,91 & 115,3 & 375 & 35 & 78 & 27 & 7,6 & 0,11 & 11,08 & 84,1 & $0,735,6$ & 2,28 & 839 & 11,8 \\
\hline 4590 & Mt. Guardia & 1,08 & 10355 & 0,2152 & 288 & 0 & 213 & 0,91 & 15,1 & 162 & 35 & 78 & 30 & 7,7 & 0,11 & 11,06 & 63,9 & $0,785,8$ & 2,23 & 339 & 11,9 \\
\hline 4594 & Mt. Guardia & 1,20 & 10113 & 0,2151 & 278 & 0 & 217 & 0,97 & 714,7 & 766 & 34 & 75 & 28 & 7,4 & 0,12 & 21,06 & 64,0 & $0,765,9$ & 2,23 & 338 & 11,7 \\
\hline 4597 & Mt. Guardia & 1,01 & 10091 & 0,2149 & 283 & 0 & 212 & 0,90 & 15,0 & 069 & 35 & 76 & 30 & 7,7 & 0,11 & 11,06 & 64,1 & $0,775,5$ & 2,23 & 339 & 11,7 \\
\hline 4600 & Mt. Guardia & 0,93 & 10131 & 0,2049 & 286 & 0 & 212 & 0,94 & 415,2 & 251 & 35 & 78 & 28 & 7,6 & 0,11 & 11,04 & 44,1 & $0,765,6$ & 2,25 & 539 & 12,4 \\
\hline 4615 & Mt. Guardia & 0,97 & 10309 & 0,2051 & 289 & 0 & 216 & 0,95 & 515,5 & 557 & 36 & 80 & 30 & 7,6 & 0,11 & 11,06 & 64,2 & $0,775,7$ & 2,25 & 540 & 12,3 \\
\hline 4620 & Mt. Guardia & 0,93 & 10164 & 0,2150 & 289 & 0 & 237 & 0,91 & 115,2 & 248 & 36 & 78 & 31 & 7,7 & 0,11 & 11,07 & 74,1 & $0,765,5$ & 2,24 & 439 & 12,3 \\
\hline 4638 & Mt. Guardia & 0,99 & 10225 & 0,2149 & 290 & 0 & 225 & 0,94 & 415,0 & 045 & 34 & 74 & 29 & 7,2 & 0,11 & 11,01 & 13,9 & $0,725,6$ & 2,27 & 739 & 12,5 \\
\hline 4639 & Mt. Guardia & 0,90 & 9876 & 0,1951 & 282 & 0 & 218 & 0,92 & 214,9 & 955 & 36 & 77 & 31 & 7,5 & 0,12 & 21,04 & 43,9 & $0,735,7$ & 2,21 & 139 & 12,4 \\
\hline 4658 & Mt. Guardia & 0,95 & 10282 & 0,2252 & 289 & 0 & 210 & 0,87 & 715,4 & & 37 & 83 & 33 & 8,2 & 0,12 & 010 & 94,2 & $0,835,6$ & 2,24 & 440 & 12,7 \\
\hline 4688 & $\begin{array}{l}\text { Canneto } \\
\text { Dentro }\end{array}$ & 1,70 & 12183 & 1,1254 & 289 & 21 & 266 & 0,97 & 715,4 & 484 & 48 & 96 & 37 & 8,0 & 0,16 & 61,05 & 54,1 & $0,776,5$ & 2,30 & 045 & 13,5 \\
\hline 4689 & $\begin{array}{l}\text { Canneto } \\
\text { Dentro }\end{array}$ & 2,42 & 13662 & 1,7856 & 282 & 91 & 296 & 1,00 & 15,2 & 290 & 44 & 93 & 30 & 8,2 & 0,20 & 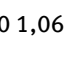 & 64,6 & $0,776,6$ & 2,20 & 045 & 12,9 \\
\hline 4694 & $\begin{array}{l}\text { Canneto } \\
\text { Dentro }\end{array}$ & 1,35 & & 0,8558 & 297 & 88 & 266 & 1,04 & & 1105 & 44 & 98 & 34 & 8,4 & & & 34,8 & $0,786,4$ & 2,33 & 347 & 13,8 \\
\hline 4696 & $\begin{array}{l}\text { Canneto } \\
\text { Dentro }\end{array}$ & 1,56 & 11774 & 0,9152 & 289 & - & 263 & 1,00 & 15,7 & 762 & 44 & 95 & 32 & 8,3 & 0,16 & 61,07 & 74,8 & $0,826,3$ & 2,24 & 447 & 13,5 \\
\hline 4699 & $\begin{array}{l}\text { Canneto } \\
\text { Dentro }\end{array}$ & 1,66 & 12187 & 1,3451 & 280 & 18 & 243 & 0,97 & 715,2 & 260 & 44 & 94 & 31 & 8,2 & & 61,06 & 64,4 & $0,806,1$ & 2,19 & 945 & 14,1 \\
\hline 4702 & $\begin{array}{l}\text { Canneto } \\
\text { Dentro }\end{array}$ & 1,76 & 12505 & 1,2557 & 284 & 33 & 262 & 0,97 & 715,4 & 454 & 43 & 96 & 31 & 8,3 & 0,17 & 71,04 & 44,8 & $0,796,2$ & 2,20 & 046 & 13,2 \\
\hline 4705 & $\begin{array}{l}\text { Canneto } \\
\text { Dentro }\end{array}$ & 1,51 & 12144 & 1,0655 & 285 & 31 & 250 & 1,00 & 15,5 & 594 & 44 & 94 & 31 & 8,2 & 0,16 & 61,08 & 85,5 & $0,786,1$ & 2,23 & 346 & 13,1 \\
\hline 4706 & $\begin{array}{l}\text { Canneto } \\
\text { Dentro }\end{array}$ & 1,74 & 12577 & 1,1656 & 290 & 82 & 298 & 1,00 & 15,7 & 768 & 45 & 97 & 36 & 8,3 & 0,18 & 81,10 & 04,6 & $0,816,6$ & 2,29 & 947 & 13,8 \\
\hline 4710 & $\begin{array}{l}\text { Canneto } \\
\text { Dentro }\end{array}$ & 2,17 & 12791 & 1,4358 & 290 & 91 & 258 & 0,98 & 815,8 & 866 & 44 & 95 & 34 & 8,3 & 0,18 & 81,07 & 75,3 & $0,816,3$ & 2,25 & 547 & 13,9 \\
\hline 4817 & $\begin{array}{l}\text { Gabellotto } \\
\text { Gorge - north }\end{array}$ & 1,13 & 12078 & 0,3961 & 301 & 0 & 302 & 1,08 & 816,9 & 9107 & 57 & 123 & 42 & 9,3 & 0,15 & 51,12 & 25,0 & $0,837,0$ & 2,42 & 254 & 15,0 \\
\hline
\end{tabular}


Table 1. INAA analyses of Lipari subsources.

\begin{tabular}{|c|c|c|c|c|c|c|c|c|c|c|c|c|c|c|c|c|c|c|c|}
\hline USF \# & Area & Sc & $\mathrm{Fe}$ & Co & $\mathbf{R b}$ & $\mathrm{Sr}$ & $\mathrm{Zr}$ & Sb & Cs $\mathrm{Ba}$ & La & $\mathrm{Ce}$ & Nd & Sm & Eu & Tb & $\mathbf{Y b}$ & Lu & Ta & U \\
\hline 4818 & $\begin{array}{l}\text { Gabellotto } \\
\text { Gorge - north }\end{array}$ & 1,09 & 11539 & 0,3861 & 292 & 0 & 288 & 1,06 & 16,292 & 61 & 120 & 41 & 8,6 & 0,15 & 51,06 & 64,1 & $0,806,7$ & 2,3950 & 14,8 \\
\hline 4819 & $\begin{array}{l}\text { Gabellotto } \\
\text { Gorge - north }\end{array}$ & 1,11 & 11801 & 0,3761 & 296 & 0 & 309 & 1,07 & 16,484 & 63 & 123 & 45 & 8,8 & 0,14 & 41,11 & 14,1 & $0,816,9$ & 2,4051 & 14,9 \\
\hline 4820 & $\begin{array}{l}\text { Gabellotto } \\
\text { Gorge - north }\end{array}$ & 1,11 & 11805 & 0,3761 & 299 & 0 & 295 & 1,09 & 16,564 & 62 & 123 & 38 & 8,7 & 0,15 & 51,09 & 94,2 & $0,806,9$ & 2,4350 & 14,8 \\
\hline 4821 & $\begin{array}{l}\text { Gabellotto } \\
\text { Gorge - north }\end{array}$ & 1,12 & 11983 & 0,3761 & 300 & 0 & 283 & 1,14 & 16,755 & 63 & 123 & 40 & 8,8 & 0,14 & 41,09 & 94,1 & $0,796,9$ & 2,4751 & 14,7 \\
\hline 4825 & $\begin{array}{l}\text { Gabellotto } \\
\text { Gorge - base }\end{array}$ & 0,95 & 11303 & 0,3257 & 295 & 0 & 275 & 1,06 & 15,978 & 53 & 106 & 39 & 8,5 & 0,14 & 41,09 & 94,0 & $0,796,6$ & 2,3647 & 14,0 \\
\hline 4826 & $\begin{array}{l}\text { Gabellotto } \\
\text { Gorge - base }\end{array}$ & 0,98 & 11556 & 0,3558 & 296 & 0 & 281 & 1,07 & 16,182 & 55 & 108 & 37 & 8,6 & 0,13 & 31,12 & 24,2 & $0,816,7$ & 2,4348 & 15,2 \\
\hline 4827 & $\begin{array}{l}\text { Gabellotto } \\
\text { Gorge - base }\end{array}$ & 0,95 & 11321 & 0,3654 & 299 & 0 & 298 & 0,96 & 16,182 & 53 & 107 & 40 & 8,5 & 0,13 & 31,10 & 4,3 & $0,886,6$ & 2,4048 & 14,2 \\
\hline 4828 & $\begin{array}{l}\text { Gabellotto } \\
\text { Gorge - base }\end{array}$ & 0,96 & 11191 & 0,3358 & 293 & 0 & 289 & 1,12 & 15,882 & 53 & 106 & 32 & 8,3 & 0,14 & 41,07 & 74,0 & $0,786,5$ & 2,3447 & 14,6 \\
\hline 5841 & $\begin{array}{l}\text { Gabellotto } \\
\text { Gorge - base }\end{array}$ & 0,94 & 11151 & 0,3456 & 290 & 0 & 279 & 0,96 & 15,866 & 51 & 104 & 33 & 8,0 & 0,13 & 31,07 & 74,1 & $0,786,5$ & 2,3647 & 13,6 \\
\hline 5842 & $\begin{array}{l}\text { Gabellotto } \\
\text { Gorge - base }\end{array}$ & 0,94 & 11213 & 0,3453 & 287 & 0 & 259 & 0,93 & 15,774 & 52 & 104 & 36 & 7,9 & 0,13 & 31,08 & 83,9 & $0,816,5$ & 2,2947 & 14,0 \\
\hline 5843 & $\begin{array}{l}\text { Gabellotto } \\
\text { Gorge - base }\end{array}$ & 0,93 & 11091 & 0,3453 & 288 & 0 & 256 & 0,95 & 15,70 & 51 & 104 & 34 & 7,9 & 0,13 & 31,05 & 54,0 & $0,806,5$ & 2,3246 & 13,4 \\
\hline 5844 & $\begin{array}{l}\text { Gabellotto } \\
\text { Gorge - base }\end{array}$ & 0,94 & 11113 & 0,3353 & 289 & 0 & 279 & 0,98 & 15,762 & 51 & 104 & 38 & 8,0 & 0,13 & 31,09 & 94,0 & $0,816,5$ & 2,3347 & 13,1 \\
\hline 5845 & $\begin{array}{l}\text { Gabellotto } \\
\text { Gorge - base }\end{array}$ & 0,96 & 11417 & 0,3545 & 267 & 0 & 268 & 1,02 & 14,354 & 53 & 108 & 38 & 8,1 & 0,13 & 31,06 & 64,0 & $0,796,6$ & 2,4047 & 13,0 \\
\hline 5846 & $\begin{array}{l}\text { Gabellotto } \\
\text { Gorge - base }\end{array}$ & 0,94 & 11166 & 0,3354 & 289 & 0 & 262 & 0,92 & 15,876 & 52 & 104 & 40 & 7,9 & 0,13 & 31,04 & 4,4 & $0,796,5$ & 2,3447 & 13,4 \\
\hline 5848 & $\begin{array}{l}\text { Gabellotto } \\
\text { Gorge - base }\end{array}$ & 0,94 & 11176 & 0,3153 & 288 & 0 & 275 & 0,95 & 15,954 & 52 & 105 & 33 & 8,1 & 0,13 & 31,08 & 84,2 & $0,826,5$ & 2,3647 & 14,1 \\
\hline 5849 & $\begin{array}{l}\text { Gabellotto } \\
\text { Gorge - base }\end{array}$ & 0,94 & 11235 & 0,3353 & 290 & 0 & 275 & 0,96 & 15,853 & 51 & 106 & 38 & 8,1 & 0,13 & 31,08 & 84,2 & $0,806,7$ & 2,3647 & 14,1 \\
\hline 5850 & $\begin{array}{l}\text { Gabellotto } \\
\text { Gorge - base }\end{array}$ & 0,94 & 11196 & 0,3452 & 293 & 0 & 275 & 0,95 & 15,674 & 52 & 104 & 35 & 8,0 & 0,13 & 31,05 & 54,3 & $0,816,5$ & 2,3347 & 13,9 \\
\hline
\end{tabular}

\section{Analysis by LA-ICP-MS at MURR}

The obsidian samples were analyzed by LA-ICP-MS using a Thermo Elemental Axiom high resolution magnetic sector ICP capable of resolving masses as close as 0.001 atomic mass units apart. The ICP-MS was coupled to a Merchantek Nd-YAG 213-nanometer laser ablation unit in which 10 samples were mounted at any one time. The laser was operated at $80 \%$ power $(\sim 1.5 \mathrm{~mJ})$ using a $200 \mathrm{Fm}$ diameter beam, firing at 20 times per second. A rectangular raster pattern of approximately $4 \mathrm{~mm}^{2}$ was drawn over a relatively flat spot on each sample. The laser scanned across the raster area at $70 \mathrm{Fm}$ per second. The laser beam was allowed to pass over the ablation area one time prior to data acquisition in order to remove possible contaminants from the surface of the sample, to permit time for sample uptake, and for the argon plasma to stabilize after the introduction of fresh material. Analytes of interest were scanned three times and averaged. In most cases, the \%RSD was 5-10\%.

Standardization was accomplished by calibrating the instrument using NIST SRM-610 and SRM-612 glass wafers doped with 61 elements. Two obsidian glasses (from Glass Buttes, Oregon and Pachuca, Hidalgo, Mexico) calibrated in a round-robin exercise by the International Association of Obsidian Studies were also used. Monitoring the amount of material removed by the laser and transported to the ICP is complicated by several factors making normalization difficult. Conditions such as the texture of the sample, hardness of the sample, location of the sample in the laser chamber, laser energy, and other factors affect the amount of material 
Table 2. LA-ICP-MS analyses of Lipari subsources.

\begin{tabular}{|c|c|c|c|c|c|c|c|c|c|c|c|c|c|c|}
\hline USF \# & Area & Li & $\mathrm{Na}$ & Mg & Al & Si & $\mathbf{P}$ & K & $\mathrm{Ca}$ & Sc & $\mathrm{Ti}$ & v & $M n$ & $\mathrm{Fe}$ \\
\hline USF4560 & Mt. Guardia & 67 & 18496 & 149 & 55817 & 379466 & 66 & 29912 & 4835 & 0 & 380 & 0 & 406 & 8213 \\
\hline USF4565 & Mt. Guardia & 92 & 26536 & 178 & 67214 & 360438 & 41 & 32140 & 5476 & 1 & 431 & 0 & 477 & 11265 \\
\hline UFS4574 & Mt. Guardia & 102 & 24483 & 176 & 73286 & 356706 & 59 & 33844 & 4759 & 0 & 468 & 0 & 470 & 9904 \\
\hline USF4590 & Mt. Guardia & 94 & 25140 & 97 & 67095 & 361642 & 58 & 34469 & 5744 & 1 & 411 & 0 & 418 & 8919 \\
\hline USF4594 & Mt. Guardia & 64 & 20967 & 90 & 53289 & 378721 & 57 & 33373 & 4086 & 0 & 348 & 0 & 366 & 8325 \\
\hline USF4597 & Mt. Guardia & 71 & 17871 & 83 & 54560 & 380494 & 26 & 32150 & 3640 & 0 & 332 & 0 & 377 & 8440 \\
\hline USF4600 & Mt. Guardia & 73 & 22041 & 160 & 63826 & 369023 & 80 & 30913 & 4681 & 3 & 453 & 0 & 419 & 9001 \\
\hline USF4615 & Mt. Guardia & 68 & 22596 & 91 & 60650 & 373682 & 24 & 28891 & 4951 & 0 & 324 & 1 & 381 & 7612 \\
\hline USF4620 & Mt. Guardia & 81 & 23943 & 349 & 73965 & 351471 & 63 & 38244 & 7768 & 0 & 528 & 0 & 456 & 10549 \\
\hline USF4638 & Mt. Guardia & 94 & 23826 & 361 & 72149 & 348460 & 154 & 37918 & 8451 & 1 & 605 & 0 & 616 & 16203 \\
\hline USF4639 & Mt. Guardia & 60 & 26893 & 88 & 66407 & 359248 & 117 & 38526 & 4739 & 0 & 421 & 0 & 431 & 8906 \\
\hline USF4658 & Mt. Guardia & 56 & 18205 & 123 & 72745 & 365708 & 93 & 29432 & 4251 & 0 & 364 & 1 & 374 & 7289 \\
\hline USF4688 & Canneto Dentro & 94 & 26255 & 210 & 68682 & 359832 & 68 & 34991 & 5467 & 2 & 262 & 0 & 421 & 8272 \\
\hline USF4689 & Canneto Dentro & 78 & 19364 & 306 & 63722 & 369988 & 85 & 30137 & 5475 & 2 & 429 & 5 & 443 & 9862 \\
\hline USF4694 & Canneto Dentro & 77 & 18948 & 162 & 51370 & 381511 & 107 & 32269 & 4688 & 2 & 355 & 0 & 419 & 8597 \\
\hline USF4696 & Canneto Dentro & 78 & 22046 & 2539 & 63904 & 353464 & 172 & 29798 & 8979 & 1 & 762 & 55 & 739 & 25157 \\
\hline USF4699 & Canneto Dentro & 84 & 23972 & 219 & 67427 & 362853 & 61 & 32950 & 5456 & 1 & 507 & 1 & 398 & 9072 \\
\hline USF4702 & Canneto Dentro & 89 & 27059 & 313 & 72810 & 354446 & 81 & 34915 & 4604 & 1 & 526 & 3 & 427 & 10571 \\
\hline USF4705 & Canneto Dentro & 92 & 25435 & 235 & 75531 & 350109 & 181 & 39066 & 5925 & 2 & 453 & 5 & 448 & 10169 \\
\hline USF4706 & Canneto Dentro & 83 & 26436 & 390 & 74112 & 351912 & 76 & 35937 & 4623 & 2 & 428 & 2 & 504 & 12302 \\
\hline USF4710 & Canneto Dentro & 77 & 23332 & 303 & 65954 & 365032 & 340 & 31676 & 4615 & 0 & 441 & 2 & 432 & 9736 \\
\hline USF4817 & $\begin{array}{l}\text { Northside Gabellotto } \\
\text { Gorge }\end{array}$ & 87 & 24377 & 160 & 70897 & 359823 & 51 & 34181 & 5227 & 0 & 372 & 0 & 439 & 7965 \\
\hline USF4818 & $\begin{array}{l}\text { Northside Gabellotto } \\
\text { Gorge }\end{array}$ & 91 & 27309 & 225 & 65554 & 362016 & 65 & 32353 & 6197 & 2 & 387 & 1 & 485 & 9316 \\
\hline USF4819 & $\begin{array}{l}\text { Northside Gabellotto } \\
\text { Gorge }\end{array}$ & 72 & 20880 & 197 & 60526 & 371981 & 36 & 30210 & 4869 & 2 & 378 & 0 & 588 & 10237 \\
\hline USF4820 & $\begin{array}{l}\text { Northside Gabellotto } \\
\text { Gorge }\end{array}$ & 83 & 24443 & 170 & 69680 & 359277 & 70 & 37256 & 4629 & 0 & 258 & 0 & 453 & 8443 \\
\hline USF4821 & $\begin{array}{l}\text { Northside Gabellotto } \\
\text { Gorge }\end{array}$ & 78 & 20591 & 154 & 74672 & 354829 & 780 & 31173 & 9126 & 0 & 494 & 0 & 568 & 11168 \\
\hline USF4825 & $\begin{array}{l}\text { Northside Gabellotto } \\
\text { Gorge }\end{array}$ & 79 & 17986 & 193 & 73953 & 363343 & 72 & 28760 & 5511 & 1 & 433 & 0 & 472 & 8783 \\
\hline USF4826 & $\begin{array}{l}\text { Northside Gabellotto } \\
\text { Gorge }\end{array}$ & 77 & 21085 & 189 & 57979 & 376043 & 139 & 29691 & 4997 & 1 & 366 & 1 & 443 & 7716 \\
\hline USF4827 & $\begin{array}{l}\text { Northside Gabellotto } \\
\text { Gorge }\end{array}$ & 86 & 22204 & 170 & 74838 & 356902 & 91 & 32452 & 5089 & 0 & 336 & 0 & 488 & 10585 \\
\hline USF4828 & $\begin{array}{l}\text { Northside Gabellotto } \\
\text { Gorge }\end{array}$ & 99 & 30065 & 224 & 64552 & 356660 & 50 & 41830 & 5192 & 1 & 430 & 0 & 466 & 9189 \\
\hline USF5841 & $\begin{array}{l}\text { Base of Gabellotto } \\
\text { Gorge }\end{array}$ & 85 & 32373 & 202 & 68170 & 350820 & 72 & 43171 & 5245 & 1 & 462 & 0 & 413 & 9719 \\
\hline USF5842 & $\begin{array}{l}\text { Base of Gabellotto } \\
\text { Gorge }\end{array}$ & 82 & 27116 & 256 & 59911 & 363585 & 39 & 40010 & 5015 & 1 & 428 & 1 & 461 & 9333 \\
\hline USF5843 & $\begin{array}{l}\text { Base of Gabellotto } \\
\text { Gorge }\end{array}$ & 94 & 28632 & 197 & 63638 & 358035 & 54 & 42402 & 4705 & 1 & 435 & 1 & 477 & 9655 \\
\hline USF5844 & $\begin{array}{l}\text { Base of Gabellotto } \\
\text { Gorge }\end{array}$ & 82 & 28224 & 218 & 59463 & 364343 & 86 & 37430 & 5315 & 0 & 464 & 0 & 476 & 9633 \\
\hline USF5845 & $\begin{array}{l}\text { Base of Gabellotto } \\
\text { Gorge }\end{array}$ & 19 & 38774 & 165 & 77264 & 339201 & 101 & 37247 & 5343 & 1 & 531 & 0 & 262 & 14210 \\
\hline USF5846 & $\begin{array}{l}\text { Northside Gabellotto } \\
\text { Gorge }\end{array}$ & 89 & 28202 & 191 & 57661 & 365659 & 67 & 38997 & 5095 & 1 & 367 & 0 & 449 & 9158 \\
\hline USF5848 & $\begin{array}{l}\text { Northside Gabellotto } \\
\text { Gorge }\end{array}$ & 56 & 20467 & 640 & 49242 & 381377 & 135 & 30964 & 5392 & 2 & 483 & 7 & 386 & 9836 \\
\hline USF5849 & Gabellotto Gorge & 83 & 27747 & 183 & 59565 & 366295 & 58 & 36426 & 4369 & 1 & 416 & 1 & 439 & 8980 \\
\hline USF5850 & Gabellotto Gorge & 127 & 31184 & 201 & 72160 & 346199 & 52 & 47419 & 4871 & 2 & 454 & 0 & 472 & 9254 \\
\hline
\end{tabular}


Table 2. LA-ICP-MS analyses of Lipari subsources.

\begin{tabular}{|c|c|c|c|c|c|c|c|c|c|c|c|c|c|c|c|c|c|c|c|c|}
\hline USF \# & Area & Co & $\mathrm{Cu}$ & $\mathrm{Zn}$ & $\mathbf{R b}$ & $\mathrm{Sr}$ & $\mathbf{Y}$ & $\mathrm{Zr}$ & $\mathrm{Nb}$ & $\mathbf{S b}$ & Cs & $\mathrm{Ba}$ & La & $\mathrm{Ce}$ & $\mathrm{Pr}$ & Nd & Sm & $\mathrm{Eu}$ & Gd & Tb \\
\hline USF4560 & Mt. Guardia & 0 & 4 & 28 & 236 & 6 & 37 & 111 & 42 & 1 & 13 & 2 & 30 & 70 & 8 & 33 & 8 & 0 & 6 & 1 \\
\hline USF4565 & Mt. Guardia & 0 & 22 & 33 & 304 & 9 & 40 & 131 & 62 & 1 & 13 & 6 & 32 & 73 & 8 & 36 & 7 & 0 & 6 & 1 \\
\hline UFS4574 & Mt. Guardia & 1 & 4 & 29 & 302 & 5 & 49 & 154 & 74 & 1 & 17 & 6 & 46 & 85 & 10 & 39 & 9 & 0 & 8 & 1 \\
\hline USF4590 & Mt. Guardia & 0 & 6 & 28 & 276 & 7 & 39 & 111 & 51 & 1 & 15 & 4 & 39 & 77 & 8 & 35 & 8 & 0 & 7 & 1 \\
\hline USF4594 & Mt. Guardia & 0 & 3 & 25 & 301 & 4 & 30 & 82 & 43 & 1 & 13 & 4 & 27 & 59 & 6 & 27 & 6 & 0 & 5 & 1 \\
\hline USF4597 & Mt. Guardia & 1 & 13 & 19 & 252 & 3 & 37 & 116 & 50 & 1 & 12 & 2 & 27 & 55 & 7 & 25 & 6 & 0 & 5 & 1 \\
\hline USF4600 & Mt. Guardia & 0 & 11 & 35 & 289 & 7 & 49 & 122 & 55 & 1 & 13 & 6 & 29 & 66 & 8 & 31 & 8 & 0 & 6 & 1 \\
\hline USF4615 & Mt. Guardia & 0 & 6 & 17 & 254 & 4 & 28 & 111 & 40 & 1 & 12 & 4 & 28 & 60 & 6 & 29 & 7 & 0 & 5 & 1 \\
\hline USF4620 & Mt. Guardia & 0 & 5 & 34 & 288 & 6 & 38 & 136 & 52 & 1 & 15 & 4 & 36 & 69 & 8 & 34 & 7 & 0 & 7 & 1 \\
\hline USF4638 & Mt. Guardia & 0 & 418 & 74 & 285 & 6 & 76 & 157 & 56 & 1 & 14 & 6 & 54 & 106 & 14 & 56 & 15 & 0 & 14 & 2 \\
\hline USF4639 & Mt. Guardia & 0 & 353 & 64 & 309 & 5 & 37 & 115 & 53 & 1 & 19 & 5 & 35 & 75 & 8 & 31 & 7 & 0 & 5 & 1 \\
\hline USF4658 & Mt. Guardia & 0 & 390 & 50 & 301 & 9 & 30 & 138 & 49 & 1 & 14 & 8 & 34 & 74 & 8 & 32 & 7 & 0 & 5 & 1 \\
\hline USF4688 & Canneto Dentro & 0 & 7 & 29 & 306 & 6 & 35 & 130 & 45 & 1 & 16 & 10 & 43 & 95 & 10 & 41 & 8 & 0 & 6 & 1 \\
\hline USF4689 & Canneto Dentro & 0 & 11 & 32 & 269 & 18 & 36 & 136 & 63 & 1 & 13 & 21 & 45 & 81 & 8 & 35 & 7 & 0 & 6 & 1 \\
\hline USF4694 & Canneto Dentro & 0 & 10 & 28 & 258 & 9 & 26 & 125 & 44 & 1 & 14 & 19 & 45 & 82 & 9 & 37 & 6 & 0 & 6 & 1 \\
\hline USF4696 & Canneto Dentro & 5 & 10 & 32 & 255 & 46 & 49 & 155 & 41 & 0 & 12 & 47 & 50 & 93 & 10 & 40 & 9 & 0 & 7 & 1 \\
\hline USF4699 & Canneto Dentro & 0 & 4 & 22 & 263 & 10 & 40 & 128 & 49 & 1 & 14 & 16 & 47 & 87 & 9 & 42 & 7 & 0 & 6 & 1 \\
\hline USF4702 & Canneto Dentro & 0 & 7 & 33 & 279 & 9 & 30 & 138 & 63 & 1 & 16 & 17 & 46 & 93 & 9 & 37 & 7 & 0 & 5 & 1 \\
\hline USF4705 & Canneto Dentro & 0 & 11 & 28 & 254 & 16 & 33 & 146 & 50 & 1 & 16 & 22 & 55 & 102 & 12 & 48 & 9 & 0 & 7 & 1 \\
\hline USF4706 & Canneto Dentro & 2 & 13 & 32 & 337 & 18 & 33 & 154 & 48 & 0 & 12 & 18 & 38 & 76 & 8 & 32 & 6 & 0 & 5 & 1 \\
\hline USF4710 & Canneto Dentro & 0 & 8 & 38 & 251 & 21 & 37 & 131 & 47 & 1 & 16 & 25 & 46 & 92 & 10 & 42 & 7 & 0 & 5 & 1 \\
\hline USF4817 & $\begin{array}{l}\text { Northside Gabellotto } \\
\text { Gorge }\end{array}$ & 0 & 9 & 21 & 247 & 14 & 36 & 155 & 48 & 1 & 15 & 13 & 66 & 111 & 11 & 44 & 8 & 0 & 8 & 1 \\
\hline USF4818 & $\begin{array}{l}\text { Northside Gabellotto } \\
\text { Gorge }\end{array}$ & 0 & 8 & 32 & 311 & 11 & 35 & 170 & 67 & 1 & 15 & 13 & 54 & 123 & 11 & 50 & 7 & 0 & 6 & 1 \\
\hline USF4819 & $\begin{array}{l}\text { Northside Gabellotto } \\
\text { Gorge }\end{array}$ & 0 & 50 & 23 & 303 & 9 & 43 & 153 & 58 & 1 & 13 & 14 & 60 & 105 & 10 & 47 & 9 & 0 & 7 & 1 \\
\hline USF4820 & $\begin{array}{l}\text { Northside Gabellotto } \\
\text { Gorge }\end{array}$ & 0 & 9 & 35 & 289 & 11 & 36 & 146 & 48 & 1 & 15 & 14 & 53 & 82 & 8 & 35 & 5 & 0 & 4 & 1 \\
\hline USF4821 & $\begin{array}{l}\text { Northside Gabellotto } \\
\text { Gorge }\end{array}$ & 0 & 31 & 37 & 282 & 12 & 57 & 158 & 48 & 1 & 16 & 13 & 82 & 150 & 16 & 65 & 13 & 0 & 11 & 2 \\
\hline USF4825 & $\begin{array}{l}\text { Northside Gabellotto } \\
\text { Gorge }\end{array}$ & 0 & 5 & 50 & 261 & 16 & 40 & 204 & 43 & 0 & 10 & 5 & 46 & 86 & 10 & 38 & 9 & 0 & 7 & 1 \\
\hline USF4826 & $\begin{array}{l}\text { Northside Gabellotto } \\
\text { Gorge }\end{array}$ & 0 & 6 & 23 & 259 & 14 & 30 & 123 & 36 & 1 & 13 & 19 & 85 & 132 & 11 & 53 & 8 & 0 & 6 & 1 \\
\hline USF4827 & $\begin{array}{l}\text { Northside Gabellotto } \\
\text { Gorge }\end{array}$ & 0 & 11 & 41 & 301 & 11 & 42 & 203 & 63 & 1 & 17 & 13 & 57 & 104 & 10 & 44 & 8 & 0 & 7 & 1 \\
\hline USF4828 & $\begin{array}{l}\text { Northside Gabellotto } \\
\text { Gorge }\end{array}$ & 1 & 10 & 54 & 293 & 11 & 28 & 121 & 34 & 1 & 15 & 8 & 38 & 80 & 8 & 37 & 6 & 0 & 5 & 1 \\
\hline USF5841 & $\begin{array}{l}\text { Base of Gabellotto } \\
\text { Gorge }\end{array}$ & 0 & 6 & 47 & 300 & 12 & 33 & 164 & 46 & 1 & 18 & 13 & 46 & 102 & 9 & 41 & 6 & 0 & 6 & 1 \\
\hline USF5842 & $\begin{array}{l}\text { Base of Gabellotto } \\
\text { Gorge }\end{array}$ & 1 & 9 & 51 & 292 & 26 & 29 & 133 & 35 & 1 & 16 & 115 & 39 & 86 & 9 & 38 & 6 & 0 & 5 & 1 \\
\hline USF5843 & $\begin{array}{l}\text { Base of Gabellotto } \\
\text { Gorge }\end{array}$ & 0 & 14 & 68 & 316 & 10 & 27 & 126 & 37 & 1 & 15 & 11 & 39 & 89 & 8 & 37 & 5 & 0 & 6 & 1 \\
\hline USF5844 & $\begin{array}{l}\text { Base of Gabellotto } \\
\text { Gorge }\end{array}$ & 1 & 13 & 57 & 292 & 11 & 27 & 133 & 33 & 1 & 14 & 10 & 40 & 87 & 8 & 37 & 6 & 0 & 5 & 1 \\
\hline USF5845 & $\begin{array}{l}\text { Base of Gabellotto } \\
\text { Gorge }\end{array}$ & 0 & 8 & 26 & 163 & 15 & 37 & 193 & 65 & 1 & 4 & 13 & 41 & 63 & 7 & 34 & 6 & 0 & 7 & 1 \\
\hline USF5846 & $\begin{array}{l}\text { Northside Gabellotto } \\
\text { Gorge }\end{array}$ & 0 & 30 & 61 & 280 & 10 & 28 & 122 & 36 & 1 & 15 & 10 & 38 & 83 & 8 & 37 & 6 & 0 & 6 & 1 \\
\hline USF5848 & $\begin{array}{l}\text { Northside Gabellotto } \\
\text { Gorge }\end{array}$ & 1 & 58 & 52 & 195 & 55 & 24 & 111 & 29 & 1 & 14 & 64 & 38 & 88 & 9 & 41 & 6 & 0 & 5 & 1 \\
\hline USF5849 & Gabellotto Gorge & 0 & 9 & 53 & 258 & 10 & 29 & 144 & 38 & 1 & 15 & 11 & 41 & 90 & 8 & 40 & 6 & 0 & 7 & 1 \\
\hline USF5850 & Gabellotto Gorge & 0 & 3 & 47 & 250 & 12 & 35 & 150 & 45 & 1 & 18 & 13 & 46 & 91 & 10 & 46 & 7 & 0 & 7 & 1 \\
\hline
\end{tabular}


Table 2. LA-ICP-MS analyses of Lipari subsources.

\begin{tabular}{|c|c|c|c|c|c|c|c|c|c|c|c|}
\hline USF \# & Area & Dy & Ho & $\mathrm{Er}$ & $\mathrm{Tm}$ & $\mathbf{Y b}$ & Lu & $\mathrm{Hf}$ & $\mathrm{Pb}$ & Th & U \\
\hline USF4560 & Mt. Guardia & 7 & 1 & 4 & 1 & 4 & 1 & 5 & 21 & 37 & 12 \\
\hline USF4565 & Mt. Guardia & 5 & 1 & 3 & 0 & 4 & 1 & 5 & 25 & 39 & 15 \\
\hline UFS4574 & Mt. Guardia & 8 & 1 & 4 & 1 & 4 & 1 & 4 & 22 & 40 & 14 \\
\hline USF4590 & Mt. Guardia & 7 & 1 & 4 & 1 & 3 & 1 & 4 & 25 & 39 & 13 \\
\hline USF4594 & Mt. Guardia & 5 & 1 & 3 & 0 & 3 & 1 & 3 & 27 & 32 & 14 \\
\hline USF4597 & Mt. Guardia & 6 & 1 & 4 & 1 & 4 & 1 & 4 & 17 & 28 & 11 \\
\hline USF4600 & Mt. Guardia & 6 & 1 & 3 & 1 & 4 & 1 & 5 & 23 & 33 & 12 \\
\hline USF4615 & Mt. Guardia & 6 & 1 & 4 & 1 & 3 & 1 & 5 & 23 & 32 & 13 \\
\hline USF4620 & Mt. Guardia & 7 & 1 & 4 & 1 & 5 & 1 & 5 & 24 & 40 & 15 \\
\hline USF4638 & Mt. Guardia & 14 & 2 & 7 & 1 & 7 & 1 & 7 & 28 & 45 & 13 \\
\hline USF4639 & Mt. Guardia & 6 & 1 & 4 & 1 & 4 & 1 & 4 & 34 & 39 & 15 \\
\hline USF4658 & Mt. Guardia & 6 & 1 & 4 & 0 & 3 & 0 & 5 & 26 & 39 & 14 \\
\hline USF4688 & Canneto Dentro & 7 & 1 & 4 & 0 & 3 & 1 & 5 & 23 & 41 & 17 \\
\hline USF4689 & Canneto Dentro & 6 & 1 & 3 & 0 & 4 & 1 & 4 & 21 & 44 & 15 \\
\hline USF4694 & Canneto Dentro & 7 & 1 & 4 & 0 & 3 & 0 & 5 & 26 & 48 & 17 \\
\hline USF4696 & Canneto Dentro & 7 & 1 & 5 & 1 & 5 & 1 & 5 & 20 & 43 & 13 \\
\hline USF4699 & Canneto Dentro & 7 & 1 & 5 & 1 & 3 & 1 & 5 & 18 & 41 & 15 \\
\hline USF4702 & Canneto Dentro & 7 & 1 & 4 & 1 & 4 & 1 & 5 & 21 & 43 & 16 \\
\hline USF4705 & Canneto Dentro & 7 & 1 & 5 & 1 & 5 & 1 & 5 & 22 & 51 & 17 \\
\hline USF4706 & Canneto Dentro & 5 & 1 & 3 & 0 & 3 & 1 & 4 & 20 & 35 & 14 \\
\hline USF4710 & Canneto Dentro & 7 & 1 & 4 & 1 & 3 & 1 & 5 & 24 & 43 & 16 \\
\hline USF4817 & $\begin{array}{l}\text { Northside Gabellotto } \\
\text { Gorge }\end{array}$ & 7 & 1 & 4 & 1 & 5 & 1 & 7 & 23 & 50 & 16 \\
\hline USF4818 & $\begin{array}{l}\text { Northside Gabellotto } \\
\text { Gorge }\end{array}$ & 7 & 1 & 3 & 1 & 4 & 1 & 5 & 24 & 49 & 19 \\
\hline USF4819 & $\begin{array}{l}\text { Northside Gabellotto } \\
\text { Gorge }\end{array}$ & 6 & 1 & 4 & 1 & 4 & 1 & 7 & 23 & 54 & 17 \\
\hline USF4820 & $\begin{array}{l}\text { Northside Gabellotto } \\
\text { Gorge }\end{array}$ & 6 & 1 & 3 & 0 & 4 & 1 & 5 & 22 & 38 & 14 \\
\hline USF4821 & $\begin{array}{l}\text { Northside Gabellotto } \\
\text { Gorge }\end{array}$ & 9 & 1 & 5 & 1 & 5 & 1 & 6 & 27 & 52 & 17 \\
\hline USF4825 & $\begin{array}{l}\text { Northside Gabellotto } \\
\text { Gorge }\end{array}$ & 5 & 1 & 5 & 1 & 5 & 1 & 5 & 23 & 55 & 16 \\
\hline USF4826 & $\begin{array}{l}\text { Northside Gabellotto } \\
\text { Gorge }\end{array}$ & 7 & 1 & 4 & 1 & 4 & 1 & 5 & 25 & 42 & 14 \\
\hline USF4827 & $\begin{array}{l}\text { Northside Gabellotto } \\
\text { Gorge }\end{array}$ & 7 & 1 & 4 & 1 & 4 & 1 & 6 & 23 & 50 & 17 \\
\hline USF4828 & $\begin{array}{l}\text { Northside Gabellotto } \\
\text { Gorge }\end{array}$ & 4 & 1 & 3 & 0 & 4 & 1 & 5 & 28 & 44 & 17 \\
\hline USF5841 & $\begin{array}{l}\text { Base of Gabellotto } \\
\text { Gorge }\end{array}$ & 5 & 1 & 3 & 1 & 4 & 1 & 5 & 29 & 44 & 18 \\
\hline USF5842 & $\begin{array}{l}\text { Base of Gabellotto } \\
\text { Gorge }\end{array}$ & 6 & 1 & 4 & 0 & 5 & 1 & 5 & 30 & 45 & 17 \\
\hline USF5843 & $\begin{array}{l}\text { Base of Gabellotto } \\
\text { Gorge }\end{array}$ & 5 & 1 & 3 & 0 & 4 & 1 & 5 & 26 & 40 & 16 \\
\hline USF5844 & $\begin{array}{l}\text { Base of Gabellotto } \\
\text { Gorge }\end{array}$ & 6 & 1 & 4 & 1 & 4 & 1 & 6 & 28 & 45 & 16 \\
\hline USF5845 & $\begin{array}{l}\text { Base of Gabellotto } \\
\text { Gorge }\end{array}$ & 6 & 1 & 4 & 1 & 5 & 1 & 8 & 56 & 44 & 13 \\
\hline USF5846 & $\begin{array}{l}\text { Northside Gabellotto } \\
\text { Gorge }\end{array}$ & 5 & 1 & 3 & 0 & 4 & 0 & 5 & 27 & 44 & 17 \\
\hline USF5848 & $\begin{array}{l}\text { Northside Gabellotto } \\
\text { Gorge }\end{array}$ & 5 & 1 & 3 & 0 & 4 & 0 & 4 & 27 & 42 & 16 \\
\hline USF5849 & Gabellotto Gorge & 6 & 1 & 3 & 1 & 4 & 1 & 5 & 24 & 46 & 17 \\
\hline USF5850 & Gabellotto Gorge & 6 & 1 & 4 & 0 & 4 & 1 & 5 & 26 & 45 & 19 \\
\hline
\end{tabular}


introduced to the torch. A normalization method described by Gratuze et al. (2001) describes the method employed.

About 40 elements were measured using a resolution of 6000 . The high resolution was necessary to reduce the number of ions striking the multiplier caused by several of the high concentration elements (Na, $\mathrm{Al}, \mathrm{Si}, \mathrm{K}$, and Fe). Relative concentrations for all elements were determined by comparing the unknowns to the NIST glass and obsidian standards. To convert the relative concentrations into absolute values, normalization was accomplished converting the relative concentrations to oxides and then normalizing the total to $100 \%$. This method yielded satisfactory concentrations for all major and trace elements.

\section{Analysis by XRF at MURR}

Energy-Dispersive X-Ray Fluorescence analysis was performed using a Spectro X-lab 2000 equipped with a Bragg-polarized excitation source. Because plane-polarized photons may not scatter into the plane of polarization, the amount of Compton and coherent scattered radiation seen by a detector when using a Bragg-polarized source in a Cartesian geometry is greatly reduced. For the Spectro X-lab 2000, with a typical degree of polarization of ca. $85 \%$, the scattered radiation background is reduced by a factor of 7 in comparison with direct excitation of the sample. This results in the detection limits and sensitivities improved by factors of 4 for geological samples. The full-width-half-maximum energy resolution of the detector used in these measurements was $135 \mathrm{eV}$ for the $5.90 \mathrm{keV}$ Mn Ka X-ray.

Obsidian samples larger than $1 \mathrm{~cm}$ diameter were mounted on the XRF with the most flat surface face downward. The XRF measurements were made using a combination of five excitation targets with a Pd anode: molybdenum for Fe thru Sr and Hf thru Th $(35 \mathrm{kV}, 4.4 \mathrm{~mA})$, aluminum oxide for Ag thru Nd (52 kV, $5.7 \mathrm{~mA})$, palladium for Y thru Mo ( $40 \mathrm{kV}, 6 \mathrm{~mA})$, cobalt for $\mathrm{K}$ thru $\mathrm{Mn}(30 \mathrm{kV}, 1 \mathrm{~mA})$, and highly-oriented pyrolytic graphite for $\mathrm{Na}$ thru $\mathrm{Cl}(15 \mathrm{kV}, 13 \mathrm{~mA})$. The method was calibrated with data from 22 pressed-pellets made from geological standard reference materials.

\section{Analysis by pXRF at USF}

Analyses by pXRF were conducted with different models of the Bruker Tracer. For all three, the same filter (0.006" $\mathrm{Cu}, .001$ ” Ti, .012" $\mathrm{Al}$ ) was used to reduce the background and enhance the precision of the results for X-rays from $17 \mathrm{keV}$ to $40 \mathrm{keV}$ which represent the K-alpha peaks for elements Fe to Mo. Model III-V+ has a Si-Pin detector, resolution approximately $190 \mathrm{eV}$ at 10,000 cps, and the excitation source a Rh target X-ray tube. The Bruker III-SD uses a silicon drift detector (SDD), with count rates greater than 100,000 cps, and thus reduced analysis time necessary. The Bruker Vi model has an even more sensitive detector, and can be run at $50 \mathrm{kV}$ and $35 \mu \mathrm{A}$, expanding the elements that may be detected and with greater sensitivity. All analyses have been conducted using the $8 \mathrm{~mm}$ beam size, with geological samples of sufficient width and infinite thickness. Analytical data are calibrated by analyzing with the same instrument a set of 40 obsidian standards produced by MURR based on values obtained from INAA, LA-ICP-MS, and XRF. pXRF analyses were also conducted on geological samples from the historic outcrops. 
Table 3. pXRF analyses of Lipari subsources.

\begin{tabular}{|c|c|c|c|c|c|c|c|c|c|}
\hline USF \# & Subsource & $\mathrm{Fe}$ & $\mathbf{R b}$ & $\mathrm{Sr}$ & $\mathbf{Y}$ & $\mathrm{Zr}$ & $\mathrm{Nb}$ & $\mathrm{Fe} / \mathrm{Sr}$ & $\mathbf{R b} / \mathrm{Sr}$ \\
\hline 4687 & Canneto Dentro & 12567 & 280 & 68 & 45 & 157 & 35 & 185 & 4,1 \\
\hline 4689 & Canneto Dentro & 12464 & 274 & 67 & 44 & 161 & 33 & 185 & 4,1 \\
\hline 4690 & Canneto Dentro & 11466 & 264 & 44 & 38 & 160 & 32 & 258 & 5,9 \\
\hline 4691 & Canneto Dentro & 12544 & 266 & 50 & 42 & 158 & 34 & 251 & 5,3 \\
\hline 4695 & Canneto Dentro & 11664 & 264 & 46 & 40 & 159 & 36 & 255 & 5,8 \\
\hline 4697 & Canneto Dentro & 10380 & 264 & 37 & 37 & 154 & 33 & 278 & 7,1 \\
\hline 4699 & Canneto Dentro & 13468 & 270 & 57 & 46 & 162 & 38 & 237 & 4,8 \\
\hline 4701 & Canneto Dentro & 12835 & 287 & 45 & 42 & 163 & 36 & 286 & 6,4 \\
\hline 4702 & Canneto Dentro & 13038 & 291 & 46 & 46 & 164 & 40 & 286 & 6,4 \\
\hline 4703 & Canneto Dentro & 11282 & 273 & 45 & 43 & 165 & 37 & 251 & 6,1 \\
\hline 4704 & Canneto Dentro & 11388 & 273 & 47 & 41 & 159 & 34 & 242 & 5,8 \\
\hline 4705 & Canneto Dentro & 10472 & 255 & 39 & 41 & 150 & 30 & 270 & 6,6 \\
\hline 4706 & Canneto Dentro & 11991 & 270 & 49 & 39 & 158 & 34 & 242 & 5,5 \\
\hline 4707 & Canneto Dentro & 10904 & 266 & 37 & 37 & 153 & 33 & 292 & 7,1 \\
\hline 4708 & Canneto Dentro & 10735 & 257 & 45 & 42 & 147 & 34 & 239 & 5,7 \\
\hline 4709 & Canneto Dentro & 11593 & 272 & 52 & 40 & 156 & 35 & 221 & 5,2 \\
\hline 4710 & Canneto Dentro & 11514 & 270 & 47 & 42 & 160 & 33 & 247 & 5,8 \\
\hline 4711 & Canneto Dentro & 11587 & 268 & 43 & 37 & 158 & 35 & 268 & 6,2 \\
\hline 4712 & Canneto Dentro & 11225 & 260 & 38 & 45 & 151 & 32 & 294 & 6,8 \\
\hline 4713 & Canneto Dentro & 12072 & 275 & 50 & 46 & 155 & 36 & 241 & 5,5 \\
\hline 4714 & Canneto Dentro & 12029 & 275 & 49 & 42 & 188 & 34 & 245 & 5,6 \\
\hline 6424 & Gabellotto & 10765 & 256 & 17 & 44 & 162 & 35 & 623 & 14,8 \\
\hline 6426 & Gabellotto & 11966 & 279 & 19 & 44 & 182 & 37 & 630 & 14,7 \\
\hline 6427 & Gabellotto & 11304 & 274 & 17 & 47 & 174 & 39 & 671 & 16,2 \\
\hline 6429 & Gabellotto & 10746 & 276 & 19 & 42 & 179 & 35 & 573 & 14,7 \\
\hline 6433 & Gabellotto & 10716 & 281 & 18 & 43 & 166 & 36 & 591 & 15,5 \\
\hline 6434 & Gabellotto & 11228 & 281 & 18 & 40 & 175 & 34 & 629 & 15,8 \\
\hline 6435 & Gabellotto & 11506 & 278 & 18 & 42 & 169 & 36 & 641 & 15,5 \\
\hline 6436 & Gabellotto & 11757 & 287 & 20 & 42 & 184 & 34 & 587 & 14,3 \\
\hline 6437 & Gabellotto & 11524 & 279 & 17 & 43 & 166 & 34 & 661 & 16,0 \\
\hline 6439 & Gabellotto & 11537 & 279 & 19 & 47 & 173 & 37 & 609 & 14,7 \\
\hline 6443 & Gabellotto & 9793 & 269 & 17 & 48 & 166 & 30 & 580 & 16,0 \\
\hline 6443 & Gabellotto & 10664 & 262 & 20 & 43 & 159 & 34 & 533 & 13,1 \\
\hline 28318 & Gabellotto & 11257 & 281 & 21 & 45 & 180 & 33 & 547 & 13,7 \\
\hline 28319 & Gabellotto & 11404 & 289 & 18 & 41 & 177 & 41 & 620 & 15,7 \\
\hline 28320 & Gabellotto & 11097 & 291 & 18 & 38 & 182 & 37 & 627 & 16,4 \\
\hline 28321 & Gabellotto & 11584 & 288 & 18 & 43 & 176 & 37 & 652 & 16,2 \\
\hline 28322 & Gabellotto & 11399 & 267 & 19 & 44 & 174 & 36 & 609 & 14,2 \\
\hline 28323 & Gabellotto & 11619 & 287 & 19 & 41 & 176 & 31 & 598 & 14,8 \\
\hline 28324 & Gabellotto & 12027 & 283 & 19 & 38 & 166 & 36 & 637 & 15,0 \\
\hline 28325 & Gabellotto & 11706 & 301 & 19 & 36 & 175 & 38 & 608 & 15,6 \\
\hline 28326 & Gabellotto & 12884 & 301 & 20 & 50 & 192 & 41 & 642 & 15,0 \\
\hline 28327 & Gabellotto & 12710 & 315 & 17 & 48 & 187 & 38 & 730 & 18,1 \\
\hline 28329 & Gabellotto & 13437 & 310 & 22 & 41 & 195 & 37 & 608 & 14,0 \\
\hline 28330 & Gabellotto & 12730 & 303 & 22 & 45 & 185 & 37 & 582 & 13,8 \\
\hline
\end{tabular}


continued Table 3. pXRF analyses of Lipari subsources.

\begin{tabular}{llllllllll}
\hline USF \# & Subsource & Fe & Rb & Sr & $\mathbf{Y}$ & $\mathbf{Z r}$ & $\mathbf{N b}$ & $\mathbf{F e} / \mathbf{S r}$ & $\mathbf{R b} / \mathbf{S r}$ \\
\hline 28331 & Gabellotto & 11080 & 288 & 18 & 44 & 183 & 35 & 623 & 16,2 \\
28332 & Gabellotto & 12608 & 301 & 19 & 45 & 194 & 42 & 674 & 16,1 \\
28333 & Gabellotto & 10423 & 248 & 15 & 34 & 160 & 36 & 690 & 16,4 \\
28334 & Gabellotto & 11226 & 266 & 21 & 44 & 173 & 35 & 534 & 12,7 \\
28335 & Gabellotto & 10273 & 305 & 17 & 33 & 185 & 29 & 609 & 18,1 \\
28336 & Gabellotto & 11019 & 263 & 20 & 41 & 169 & 38 & 553 & 13,2 \\
28337 & Gabellotto & 11438 & 283 & 19 & 37 & 177 & 36 & 615 & 15,2 \\
28338 & Gabellotto & 10971 & 266 & 18 & 50 & 176 & 32 & 611 & 14,8 \\
28339 & Gabellotto & 11213 & 273 & 17 & 42 & 184 & 32 & 673 & 16,4 \\
28340 & Gabellotto & 11433 & 277 & 18 & 43 & 168 & 38 & 653 & 15,8 \\
28341 & Gabellotto & 12845 & 307 & 26 & 34 & 171 & 35 & 497 & 11,9 \\
28342 & Gabellotto & 11561 & 280 & 26 & 31 & 178 & 31 & 436 & 10,6 \\
28343 & Gabellotto & 11004 & 250 & 16 & 43 & 162 & 27 & 688 & 15,6 \\
28344 & Gabellotto & 11850 & 271 & 19 & 45 & 182 & 32 & 633 & 14,5 \\
28345 & Gabellotto & 13848 & 341 & 20 & 44 & 194 & 39 & 694 & 17,1 \\
28346 & Gabellotto & 10554 & 270 & 13 & 40 & 160 & 35 & 812 & 20,8 \\
\hline
\end{tabular}

